\title{
Never Treat the Child as Someone with a Disability
}

\author{
Zhen Wei
}

\section{Interview with Ms. LJ's Mother}

LJ, female, born in 1991. The only child in the family. Grade III intellectual disability. Graduated from a special education school in 2008. Started working at Shanghai Papa John's in 2010.

Interviewee: LJ's mother

Interviewer and writer: Zhen Wei.

Interview dates: November 21, 2016 and April 19, 2017

Interview place: LJ's home

Note on the interview: During the interview, LJ's mother sat by the window with the interviewer while LJ played computer games in another room, separated by a curtain. We could hear each other

\section{Fate Changed by a High Fever}

Q: How did you meet your husband?

LJ's mother: Someone introduced me to him, and we got married after dating for a year. I was 23 and he was 24 . The legal age for getting a marriage certificate was 22.

Q: People have expectations for life after marriage. What were your expectations?

LJ's mother: I didn't really dwell on that. Getting married just meant having a life and a child together.

Q: LJ has a very beautiful name. Did you come up with the name?

Z. Wei $(\varangle)$

East China Normal University, 3663 Zhongshan Bei Ro., Shanghai 200062, China 
LJ's mother: The name "Wen" was very popular back then, so I just followed the trend. I figured that it was a good name for girls as it sounded nice and implied a quiet personality.

Q: Was LJ normal when she was born?

LJ's mother: Yes, she was. Like in Shanghai, babies on our farm got monthly check-ups that included vaccinations and checking the babies' development. LJ was fine.

If you don't mind my saying this, my daughter wasn't born with any intellectual disability. It was caused by a high fever. We were young and didn't know much. I actually blame the hospital for the way she is now.

She started getting a fever in the afternoon and we didn't give her any medication. The hospital was far away and we had to take a bus to get there. So her dad waited till after work to take her there. By the time they got there, the pediatrician was off and the physician who treated LJ didn't really know what he was doing. So the fever continued for another night. The hospital in the town we lived in was small and the doctor didn't refer us to another one. So LJ was throwing up the whole night while she had the fever, and eventually passed out. By 4 a.m., she had no response no matter how hard we tried to wake her up. So we knocked on the pediatrician's door even though he was off duty, and he realized that something was wrong. So you see, it was the hospital that delayed the treatment. LJ was born normal and was actually very smart at that time, when she was almost 10 months old.

Q: So she had her high fever at 10 months old?

LJ's mother: Right. Before she was 10 months old, she was really smart and energetic. Just looking at her eyes you would know that she was smart and understood everything.

Q: When did LJ learn to talk and walk?

LJ's mother: She learned to talk really early, at 1 year old. But she started walking late, at 14 months. She learned to talk before she could walk.

Q: Can you elaborate on how she was funny and naughty?

LJ's mother: She was really naughty when she was young. We were living in the Chongming countryside and she just played all the time. We bought her a small bicycle and she would be on it all day long. She was a little daredevil too. Let me show you some pictures of when she was young.

(Getting up to bring pictures from a drawer.)

I laminated pictures of when she was young and put them in albums. So the majority of what I have now are from that period of time. (Picking up one album) Not in this one. (Going to another drawer for other albums) Our life back then wasn't so bad... We were living in the Chongming countryside and I took many pictures of her.

These pictures date all the way back, some are from when she was born. This one was from when she couldn't walk yet, (pointing at the picture for the interviewer). This one, too. She was a tomboy back then, very naughty.

(Flipping through the pictures) This seemed to be from her 1-year birthday party. In the countryside, we celebrated before the baby actually turned one, so she was probably only 11 months in the picture. I am not really sure. 
(Pointing at a picture) This was from when she was three. (Flipping through the pictures) This was taken in a park when she was in first grade.

She was doing fine at the beginning, but as she grew older, she started failing school. She was okay in first grade and second grade, but third grade proved too hard for her, and it got worse from there on...

(Flipping through the pictures) This was taken at the Oriental Pearl.

Her disability wasn't apparent back then... It's just that she seemed to lag behind in intellectual development.

\section{Preferring Play to Study}

Q: How did the family take care of her before and after she started preschool? Did you go to any bonding activities or intellectual development programs?

LJ's mother: Intellectual development programs, no. We were very busy at work and had no time to teach her anything, so we let her play on her own.

We seldom taught her anything except for really simple things like one-digit addition and subtraction. But she didn't seem to learn much. At first we weren't paying attention. She didn't learn much at preschool and I figured that she would do better once she started first grade, since the teacher would teach more. She never showed much interest in the things we taught her back then, like kids' songs. She was only interested in playing.

Q: What did she play?

LJ's mother: She played with toys or other kids outside. The things she was interested in had nothing to do with studying. I asked her to study and she couldn't focus because she just wanted to play. After sitting there for $10 \mathrm{~min}$, she was done and couldn't sit or study any longer.

Q: Since both you and your husband had to work, who watched her back then?

LJ's mother: My mom took care of her. She needed to be dropped off and picked up from preschool, so sometimes I would do the dropping off and my mom would do the picking up. My daughter was quite capable. Some days I would drop her off and she would come home by herself without my mom.

Q: She could go home by herself?

LJ's mother: Yeah, she could find her way home. One time I forgot to tell my mom to pick her up and thought she knew, and she thought I would do the picking up, so LJ came home by herself.

The preschool she went to was a regular one, the kind that was affiliated with state-owned companies. We didn't check out any special education preschool or organization.

Q: LJ started with a regular elementary school and followed the same curriculum as other kids, right?

LJ's mother: Right, she was taught everything they were taught. She was very naughty when she was young, so we didn't pay attention to her intellectual ability. At preschool and in first grade, there was always something going on in her head 
and she just wanted to play all day long. She was able to keep up in first grade and second grade, but started lagging behind in third grade, because third grade is a turning point where everything becomes more difficult and a lot of repetition and rote memory is involved, like in pinyin. She doesn't have a good memory. She would study and then forget about it. People who suffer from memory loss tend not to do well academically. I figured that it also had to do with the high fever she had which had damaged her brain.

Q: Which classes did she like?

LJ's mother: She didn't like any or have any interest or the desire to learn. I asked her to study Chinese and math and she wasn't interested. She had no interest whatsoever in academics.

Q: What about music, drawing, PE, and crafts?

LJ's mother: She liked PE which was just playing outside, jumping and running. That's exactly what she liked, so she seldom got sick when she was young.

Q: At the regular school, did she like the teachers?

LJ's mother: She was a little scared of the teachers, some of whom were really strict. The teachers sometimes didn't know how to control her. But she wasn't scared of young teachers and her mind would wander off in their classes.

Q: Did the teachers give her any special treatment?

LJ's mother: The teachers would keep her after school to catch up on homework or tutor her on homework. She wasn't learning well or doing well on tests, so we would be summoned to the office. She managed to pass the tests in first grade, but failed in second grade and third grade. The third-grade curriculum was too difficult for her.

Q: What did you think of the teachers or the teachers' attitudes?

LJ's mother: I didn't give it too much thought. The teachers did their job teaching, and it was my daughter who wasn't into learning and was failing, so it wasn't the teachers' fault, was it?

Q: You mentioned just now that the teachers would keep her after school to catch up on the curriculum. Did she still have to do homework when she got home from school?

LJ's mother: Yes, she still had to do homework. She would do it but forgot about it by the time she took the tests. She was the kind of child with a bad memory. Sometimes you would teach her something and she would forget whatever she had learnt a while back, so you had to teach her repeatedly. (Laughing)

She seemed to remember when you first taught her, but would forget after some time. At the end of the semester, you are supposed to integrate everything you have learnt the whole semester, right? But she couldn't do that, she would just forget.

Q: Can you elaborate on how you tutored her with her homework?

LJ's mother: I didn't exactly tutor her. I just let her do it on her own and I would only teach her if there was anything she couldn't do.

She wouldn't say anything if there were things she couldn't do. She would just leave it blank. On the Chinese sample tests, sometimes she needed to fill in a lot of blanks but she couldn't do any, because she had to understand the Chinese text first. 
She understood nothing, so of course she couldn't fill in the blanks. At those times, I would teach her by explaining the text to her.

Q: So you didn't realize LJ's disability until she was in elementary school?

LJ's mother: Right. She was going to Bei Xing Jin Elementary School. She was born in 1991, so it must have been the year 2000 when she was at that school and we had already moved here. She couldn't keep up at school and there were disruptions in her schooling. She had to repeat second grade and third grade as well, and was dragging down the average scores of her class. So the teacher asked us to take her for an IQ test. I took her to Zhidan Road for the test and the score was bad.

Q: Did you take her to any hospital for diagnosis after the test?

LJ's mother: We didn't go to any hospital. We went to a special organization for IQ tests. An assessment was required to get a disability certificate, and that organization did the assessment.

Based on the IQ test, she had intellectual disability, so the schoolteacher suggested that she quit the regular school. She had been there several years, couldn't keep up and had to repeat the grades, so the school asked me to look into special education schools.

Q: So LJ only took the test once on Zhidan Road? You didn't double check with other organizations?

LJ's mother: She tested twice and both were on Zhidan Road. I didn't think of getting a second opinion at other organizations. For the tests, she was required to solve some problems but I'm not sure what problems.

Q: How did LJ get along with her classmates at elementary school?

LJ's mother: She got along well.

Q: Would she ask to play with them?

LJ's mother: Yes, they would play together. She played really well with her classmates, and now that she is working, she gets along really well and has no problem communicating.

Q: How did LJ go to school when she was in elementary school?

LJ's mother: When we were still living in Chongming, the school was down the block from us, so she would walk to school by herself sometimes. After we moved to Shanghai, we had to cross a major road to go to school, so I took her to school every day to be safe.

\section{Non-Challenging Curriculum at Special Education School}

Q: Did you have misgivings about her going to the special education school after third grade?

LJ's mother: How could I not? I figured that once she was there, she would be different from the average kid, because she would be labeled as having a disability and be inferior. At that time, teachers at the regular schools were not really fond of kids like her because she wasn't doing well academically and often dragged down 
the average test scores of the class. We had no choice but to send her to a special education school.

She attended regular schools till third grade before going to the special education school. She was with kids who were not smart or had disabilities till she graduated. Academic-wise, she didn't learn much. Because of her years at regular schools, she could do everything at the special education school.

Q: You are referring to knowledge?

LJ's mother: Yes, knowledge-wise. She didn't learn much, she was wasted in there. We tried to train her to be independent and not to hang out with kids from the special education school. I was told that she shouldn't seek the company of people with intellectual disabilities. For the sake of her own intellectual development, she should get to know and interact with ordinary people in the real world.

Q: What exactly did she learn at the special education school?

LJ's mother: They were taught some hands-on things. Those kids couldn't really learn much, so the teachers didn't teach a lot. My impression was that no matter what was taught, it was very simple. Their Chinese texts were simple too-too simple for LJ, actually. So whatever was taught, hands-on things or knowledge, the audience was mainly the other kids, because LJ already knew everything and could do everything. At that time, if there were things that needed to be organized or done in the class, the teacher would have my daughter handle it all by herself.

Q: So LJ was asked to handle a lot of things? Was she given some kind of title in the class?

LJ's mother: There weren't exactly any titles, because the class only had a dozen or so kids, and since the kids all had some kind of problem, the teacher didn't bother with titles. There was no class president or academic student leader. The kids were all grouped together and helping each other out. That's the way the class was.

Some kids were okay, but some even had difficulty walking and needed constant help. So my daughter would help them sometimes. In her class, there were kids with lower IQs than her and some couldn't even tie their shoes, which means that their IQ was really low. They understood next to nothing, so my daughter would help them.

Q: She must have had some extracurricular activities at the special education school? Do you still remember some?

LJ's mother: There weren't many extracurricular activities. Some kids had difficulty walking and some had difficulty talking. They did go outside with the teacher for some activities like playing with balls, but there was always the worry that some kids would fall.

The school would organize some artistic performances. My daughter was pretty chubby then, and being chubby, she didn't want to participate in the performances. She could learn dance moves really fast, like for a performance or for International Children's Day, whereas other kids couldn't learn as fast. But she was overweight and didn't like that kind of activity.

Or they would go somewhere for a competition. Special education schools do this too, like going to outside schools for performances or competitions. She would participate but wasn't really into it.

Q: So she didn't like being in performances, did she? 
LJ's mother: She was overweight and self-conscious about it. Even now she doesn't like it because of being overweight.

Q: Did she like that special education school?

LJ's mother: Not particularly. Maybe she didn't understand much. School was fun, she didn't have to study a lot and was playing all day long. My impression was that she didn't learn much, not much was going on in class or being taught, and she had a lot of freedom there.

Q: Did anything happen at the special education school that was memorable?

LJ's mother: Not really. Everything was normal and not in the least exciting. I told her that she spent so much time there that it was like a babysitting service, with not much going on.

I didn't drop her off then. And when school ended, she would go home by herself. It was like sending her to a babysitter, she didn't learn much there and at the end of the day, she just took the bus home.

Q: When did you stop dropping her off at school?

LJ's mother: When she started at the special education school. She was 13 or 14 years old by that time and supposedly fourth or fifth grade level.

Q: So you mean that starting with fourth or fifth grade, LJ went to school and went home by herself?

LJ's mother: Right, by herself. I took her to school the first day, told her the directions and she remembered. Since then, she went to school by herself and took the bus home by herself after school.

Q: Were you not worried about her safety?

LJ's mother: (Laughing) Not really. She was okay, she wasn't scared. When she was going to preschool in the Chongming countryside, sometimes my mom and I would forget to pick her up, and she was able to get home by herself.

Q: That's really good. So how long did she stay at the special education school?

LJ's mother: Four or 5 years, till she graduated. She was there from fourth grade through ninth.

Q: In Shanghai, as far as we know, special education school would be followed by 2 years' preliminary vocational school. Did L have those 2 years of preliminary vocational school?

LJ's mother: No. She stayed at the special education school through ninth grade.

Q: Through ninth grade?

LJ's mother: Yes. Back then, they stayed through ninth grade, followed by 2 years' extension, so she stayed for another 2 years. She was 16 in ninth grade and couldn't get a job, because she had to wait till she turned 18 to get a work permit. Once they turned 18, they were given jobs outside school like moving things and selling things in supermarkets.

Q: During those 2 years' extension, the school should have offered some sort of curriculum, right? Was it any different from before?

LJ's mother: I didn't see much difference. During those 2 years, the school would often arrange internships for them like at supermarkets opened by the Sunshine Home, an organization in Putuo District for people with disabilities. 
There are shelves in supermarkets, right? So they were taught to organize the shelves or greet the customers. How to welcome customers when you see them coming in, how to restock the shelves, how to check for expiration dates of items on the shelves... all of these were taught at the special education school. She got paid for those supermarket internships, but it was a minimum wage.

Q: Paid internships?

LJ's mother: Right. My daughter said back then, "Wow, I am getting paid now." The pay wasn't much, but it made her very happy, because it was the first time she got paid for making an effort.

Q: Did she get tested on what she learnt at the special education school?

LJ's mother: She did but the tests were too easy. She knew everything on the tests. She had learnt quite a bit at the regular schools and the special education school didn't teach anything difficult, so the tests were simple.

Q: Can you be more specific?

LJ's mother: The tests were on addition and subtraction below 100, so who would fail that? For Chinese, it was writing characters based on the pinyin given and the characters were all simple ones. Do you know how many Chinese characters are taught at regular schools from first to third grade? Special education schools don't really teach that many. For her, she had read the same texts before and already knew all the characters, so she had no problem with the tests at all.

Q: Did she talk to you or your husband about what she learnt at school?

LJ's mother: Not really. What she did say sometimes was that what she learnt at the special education school was too simple and she already knew all of it, which was true.

Q: Did the special education school teach hands-on skills?

LJ's mother: It did, and she could do everything.

Q: Was there any teacher at the special education school that she liked?

LJ's mother: There was a teacher, Ms. Zhang. She used to be head of academics and lived in the building next to us. She was really young. Then we moved and heard about her promotion to principal.

You should ask my daughter about Ms. Zhang. She will remember better because the two of them got along pretty well. Ms. Zhang liked my daughter. If something needed to be done at school or there was some issue, she often asked for my daughter's help, and my daughter liked her. I saw her hanging out with Ms. Zhang, sometimes even on Saturday or Sunday.

Q: There was no school on Saturday or Sunday, was there?

LJ's mother: No school. She would go out with Ms. Zhang sometimes for activities or to get some things done. Or she would go to her place. She lived next to us before we moved.

Ms. Zhang really cared about her. Before we moved, we would run into her within the apartment complex and she would ask LJ how she was doing and they would end up chatting.

Q: Is she still in touch with Ms. Zhang?

LJ's mother: We moved and live far from her now, so we are not in touch. I am not sure if my daughter has kept in touch with Ms. Zhang or has her phone number. 
Q: How did other teachers at the special education school treat LJ?

LJ's mother: They were nice, because LJ didn't bother anyone. In fact, the teachers didn't have to do much for her, so she was easier for them than some of the other kids. She could do everything by herself and didn't need much supervision, and she always helped the teachers. So the teachers were nice to her.

Q: How did the other students treat LJ?

LJ's mother: They were okay. Sometimes she would tease them. She wasn't being mean. She was just naughty and would play tricks on the other kids. And when she was unhappy, she would just ignore them and not help them.

Q: Did she make any good friends at the special education school?

LJ's mother: There was one who hasn't quite kept in touch. There was a girl named J, and another named G. I know that G has kept in touch and they have remained good friends and often hang out together.

J worked doing the same supermarket internship with my daughter after graduation. They used to hang out and go out together. But now LJ can't find her phone number and just lost contact.

Q: As she grows older, did you see any dramatic change during a certain period of time?

LJ's mother: Not in particular, except for maybe the rebellious teenage years. Now that I think about it, she wouldn't listen to me at all when she was going from 12 to 13. Must have been teenage rebellion. Whatever I said, she would contradict me and do the opposite thing. She refused to listen to us and couldn't take in what we said. Nothing I said seemed to make sense to her. But it was over after a while, so I guess it was just a short-lived rebellion.

Q: How long did it last?

LJ's mother: That rebellious phase lasted 1 to 2 years, now that I think about it.

Q: She should still be at school at age 12 or 13 . Would she have talked to her teachers or classmates?

LJ's mother: Yes, she was still at school. She didn't talk much back then. She would talk to people she got along with, but she didn't communicate much with the teachers. At the special education school, you know... She could talk to just a couple of girls whereas the other kids were not easy to communicate with. After her teenage years, she got better, much better.

Overall, I feel that she was quite normal growing up and didn't cause me too much trouble.

Now that she has grown up and started working, I do feel that she is slightly different from before. We don't have to worry about her now. I used to always worry if she went out, now I am taking it much easier. I let her go out and deal with people on her own, and I don't worry about how she talks, makes friends, or spends money. 


\section{Gratifying Supermarket Job}

Q: Did you think about what she should do after graduating from the special education school?

LJ's mother: Her dad wanted her to learn driving but I didn't think it would work, because driving needs brains for making judgment and she didn't have the brains. Another option was to do sales, but being a cashier wouldn't work either, because calculation is involved and what if she gave the wrong change? So I said no when someone asked her to work as cashier because I didn't want to cover any losses caused by her giving the wrong change.

Then I asked her to get a work permit because my niece said she could sell clothes. She didn't end up doing the job selling clothes and never had to use the work permit.

Q: Did she take the test for the work permit herself?

LJ's mother: Yes, she did. She was looking for a job and a work permit could come in handy. Sometimes you couldn't work without the permit, but once you got the permit, it didn't seem to be of much use.

Q: So she started working after the 2-year extension program. Was there any job that LJ liked at the beginning?

LJ's mother: She didn't give it much thought. She stayed home, then worked for a while at a supermarket, then lost her job when the supermarket was closed.

Q: Why was it closed?

LJ's mother: That supermarket wasn't making money, so the store was leased to another party. Someone at the top made the decision, not those running the store. No profit, no supermarket.

I was happy when the school got her the job at the supermarket and I had wanted it to be long term, but then the supermarket was closed. I figured that she would need a stable job sooner or later, and the Disabled Persons' Federation (DPF) didn't really give me many leads. It just sent me a notice asking if I wanted subsidy or insurance payment, and I picked the latter of course.

Q: Can you elaborate on the insurance payment?

LJ's mother: If you choose subsidy, you won't get any insurance payments. Her disability certificate specifies that she has medium disability which qualifies her for a monthly subsidy or monthly insurance payment. I said I didn't want subsidy and wanted insurance payments instead. I was thinking about her life in the long run. I wanted her to go out there and get a job. The DPF pays into her pension and health insurance, and her workplace has been doing the same.

Q: How long did she work at the supermarket?

LJ's mother: Not very long, about a year and a half. She got paid every month, and the supermarket paid into her social insurances too.

Q: What exactly did she do at the supermarket?

LJ's mother: Restocking, organizing shelves, and checking expiration dates and removing items that had expired. She wasn't working as a cashier. She was just organizing shelves.

Q: Did she like the job? 
LJ's mother: She liked it a lot. She went straight from school to the supermarket and had a great time.

Q: You mean she went to work at that supermarket right after graduating from the special education school?

LJ's mother: Right, that's what happened. She was very happy, because she got paid every month and was doing a good job organizing and restocking shelves. The teachers at the supermarket were very nice and taught her to check and restock the merchandise.

Q: There were teachers teaching them at the supermarket?

LJ's mother: We called them teachers, but they were just older employees at the supermarket. Since they were older than LJ and would be teaching her, we tried to be courteous by calling them "teachers."

Q: Was she happy when she got paid?

LJ's mother: Of course. It was the first time she made money. None of us were paid a lot back then and she made less than we did, but she was very happy because she was the one who made the money.

I told her to save her money and she said she would use it to buy me groceries. I refused, saying that she should keep the money for herself. She was thinking about me, thinking about using the money to buy me or her grandma something. I told her she didn't have to buy grandma anything, as long as I knew, and grandma knew, that she had such generous thoughts. She got paid for the first time in her life, and she was thinking about...

Q: About her family?

LJ's mother: Yes, about her family. She knows to give back.

Q: Does she keep her own money now or do you keep it for her?

LJ's mother: She keeps it herself. She has been doing it for the last 2 years. Before, I had been keeping it for her for several years, now she'll ask why she should let me keep her money for her. I figured she was right, so I gave the bankcard back to her and let her keep her own money.

Q: Does she spend the money?

LJ's mother: She does. She shops, like food, clothes, and whatnot. Sometimes she buys clothes she needs, and other times she doesn't really wear what she buys. She likes to eat, so she buys snacks. She spends on food, clothes, and things she uses.

Q: There were other employees at the supermarket. How many were there, do you remember?

LJ's mother: There weren't many employees. Besides LJ and her friend $\mathbf{J}$ who had just graduated from school, there were two or three employees who were in charge, and they worked shifts.

Q: How did LJ get along with her co-workers?

LJ's mother: She got along really well. It was good for her working at the supermarket and people there were pretty nice. She really liked that job. Too bad the place closed.

Those two teachers were nice and told me that LJ shouldn't hang out with people who are not very smart, because it wouldn't help with her own intellectual development, and that she should interact more with ordinary people in the real world. 
Frequent exposure to customers at the supermarket was good for training her abilities. The fact is that her thinking is definitely slower than ours and she doesn't react as fast as we do, and when there are problems to be solved, she can't cover every angle the way we can.

The two teachers also took my daughter out. They often went to Suzhou, so they took her along. My daughter doesn't look like someone who is really slow, you know, so back then, she often traveled and went out with those two teachers and other ordinary people.

Q: LJ worked shifts at the supermarket. What did she do on her days off?

LJ's mother: It depends... computer (LJ was playing computer games). She didn't go out much, she just stayed home with the computer.

Q: So she was kind of a homebody?

LJ's mother: Right, she didn't go out much. She stayed home to play games on the computer.

Q: What kind of games?

LJ's mother: I don't know what games. The computer at home is getting old and I don't know how to play games. The game that she was playing had different levels that you could get to, but I don't know what it was. What game were you playing? (Asking LJ.)

LJ: Warcraft.

LJ's mother: Warcraft. She plays computer games, watches kids' TV shows, and really clicks with my niece's husband. He is in his thirties but still watches kids' TV shows, those with endless episodes. (Laughing)

$\mathrm{Q}$ : The anime that kids watch?

LJ's mother: Japanese anime. My niece is young, just over 30, and she watches anime too. My nephew, too. They share the same language. We would go for dinner at my niece's place and they would talk about computer games, TV shows, and anime at dinner. I don't understand anything. They would be talking and I wouldn't be able to get a word in because I don't watch what they watch.

\section{A Precious Daughter}

Q: When LJ was growing up, did you and your husband disagree on how to educate her?

LJ's mother: Education is never easy. I wanted one thing sometimes and he wanted another, the two of us...

Q: What did you want?

LJ's mother: I said that since she wasn't doing well academically, we should just let her do her own thing. He said we should push her. But it's no use since she really wasn't into studies.

Q: So your husband wanted her to study harder? 
LJ's mother: Yes. I said that no matter how hard you pushed her, she would forget what she had learned before and rote memory wouldn't work. It's not that I didn't want to teach her. He said that I didn't do a good job teaching her and pushing her.

Q: Your husband said that you didn't do a good job teaching her?

LJ's mother: Yes, he said that I didn't teach her well, but if she didn't want to learn, she didn't want to learn. I wanted her to find her own way.

Q: Did your husband teach her?

LJ's mother: Never. He didn't have the time or the ability because he didn't know how. He just asked me to do it while he did nothing himself.

He can't even speak Mandarin, really. He speaks Mandarin with an accent and doesn't even know pinyin, so how could he teach her? He couldn't.

Q: Did he interact a lot with LJ? Did he take her out?

LJ's mother: Not a lot. Most of the time I was the one taking her out. He is a taxi driver and takes every other day off, and he needs to rest. When he works, he drives the taxi for $24 \mathrm{~h}$ non-stop, so on his days off, he sleeps and seldom has time to take her out. So I have always been the one taking her out.

Q: Did the grandparents on either side help out?

LJ's mother: Occasionally. Once we moved to Shanghai, they hardly helped. I was the sole caregiver.

She grew up in the Chongming countryside till third grade. In the countryside, I was the one with her most of the time. Before she went to preschool, the grandparents on her dad's side would play with her. Once she was older and started school, they stopped and she didn't want to play with them anyway.

$\mathrm{Q}$ : Since you were the one with her most of the time, where did you take her on weekends?

LJ's mother: We didn't go to many places because there were not many places to go to in the countryside, unlike in Shanghai where there are so many parks. So we would play in the communal area of the apartment complex. Once we moved to Shanghai, there were many more places to go to like parks and arcades. We didn't have those in the countryside.

Q: Once you moved here after LJ finished third grade, did she get to go out a lot?

LJ's mother: She got to go out more often. She had been to most of the parks since she could play there, unlike in the countryside.

Q: And you were still the one taking her?

LJ's mother: Yes, I was. We would row a boat and do almost everything.

Q: After you had LJ, did you and your husband consider having a second child?

LJ's mother: We didn't. It was so many years ago and we didn't know. We were told later that we were allowed to have a second child since the first one had an intellectual disability. But I didn't want to have a second child, even though we could.

Q: What about after you got LJ the disability certificate?

LJ's mother: After I got her the certificate, we were allowed to have a second child, even though I didn't know until someone told me several years later. I am old now, so why would I want to have another child? I have never seriously considered having another one, and I have never seen LJ as someone who is different. 
Q: Your husband has never discussed this with you?

LJ's mother: He has never really considered it either. We were indeed allowed to have a second child back then, but we decided against it since we have never seen LJ as someone with a disability, so there's no need to have another child, right?

Q: Have you ever had any pressure taking her out? For example, were you worried about how people would see her?

LJ's mother: Never. She has always been most precious to me. I would never say, like I am supposed to say, that she has a disability. I have never seen my daughter as inferior to anyone. She is the best as far as I am concerned.

Ever since she was born, my daughter has always been able to do everything. She is just a little overweight, and when she is overweight, she doesn't appear very smart or agile.

Q: What about your husband? Has he ever had any pressure or worries?

LJ's mother: Not exactly. He just wished that she could do better academically, and it kind of bothered him that she was failing with her studies. So what's the big deal? She is independent now and making her own money. Even though her IQ is slightly lower, it doesn't matter. That's no reason to look down on your own child!

I hate it most when people say that you are a "gang du" or have a disability. Some people will make a big deal of saying that you went to a special education school and I don't like that.

Q: "Gang du"?

LJ's mother: It's Shanghainese meaning "dumb" in Mandarin. Some people think that if you went to a special education school, you are dumb. I see many people with disabilities out there, some have intellectual disabilities and are not smart, but not all of them are like that. I see everyone the same, because my child is the same as every other child, right? I hate it most when people say, "This one has problems and is dumb." But I won't argue if I hear it. No one knows that my daughter has a disability certificate. No one knows.

Q: Because no one can tell, right?

LJ's mother: I have never told anyone, and not even the neighbors know. Why would I tell them? Some will understand, but others won't and will look at her differently. My daughter is no different from ordinary people except that she is a little overweight.

Q: What about the grandparents? Do they somehow see LJ differently?

LJ's mother: The grandparents on her dad's side don't see her differently. They see her more in the light of a girl, and in the countryside, people value boys more than girls, so we are not close to them. They wanted a grandson and ended up with a granddaughter, so that's what they are unhappy with, you know.

Q: So the issue is more about the gender of their grandchild?

LJ's mother: Right, they had a problem with her being a girl, and her grandpa on her dad's side had a problem with her not doing well academically. They knew about her getting a disability certificate and were actually okay with it.

Q: Are there any other family members? For example, uncles, aunts, older brothers, or sisters?

LJ's mother: Her dad has an elder sister and a younger sister. 
Q: How do the two aunts treat LJ?

LJ's mother: They are okay, but I don't think they like LJ much. We don't see them often. They have their lives and we have ours, and we don't live close. They live near Beixinjin in Changning District and we live here.

My daughter didn't do well academically and has no degree, so the aunts were always on her about it. They also told her to lose weight and to make herself more presentable. They don't seem to like my daughter much.

My own elder brother seems to like LJ a lot. He has one girl who is older than LJ and already married. She and LJ are very close and we often go to her place. She likes to hang out with my daughter and has never looked down on her. She is really nice.

\section{Reluctant about Going to the Sunshine Home}

Q: What was your plan for her after the supermarket was closed?

LJ's mother: After the supermarket was closed, she was told to go to the Sunshine Home and to work at the Sunshine Workshop. She went for several days and then refused to go anymore, because she said that people over there were really not smart. She had no one to talk to there because everyone was really slow.

Q: So she had no one to play with at the Sunshine Home?

LJ's mother: She could do all the crafts like making paper boxes, and it was no fun for her, so she didn't want to go anymore. She didn't want that kind of job, you know.

Q: Where was the Sunshine Home that LJ went to?

LJ's mother: It was on Tongchuan Road. She went for 1 month and then stopped.

Q: What did she do at the Sunshine Home?

LJ's mother: She took some lessons and after the lessons, she worked, like processing small things for third parties and pasting paper. Things you normally do at a workshop. And it was paid work. She was reluctant to go and didn't really go for many days.

Q: So she took lessons there?

LJ's mother: Just lessons on how to make simple things.

Q: Anything she liked to do there?

LJ's mother: Nothing she really liked. She was bored staying there all day and since the people there were really slow, she couldn't talk to them and had problems communicating with them. Previously, she mainly interacted with ordinary people. So when she went to the Sunshine Home, she found it difficult to interact with anyone there, so she didn't want to be with them and didn't want to go there. I figured that she should go there because she got paid and the Sunshine Home also paid into her social insurances. I told her about that, but she still refused to go.

Q: Even after you told her what she could get out of going to the Sunshine Home, she still didn't want to go there?

LJ's mother: Right. She refused to go because it was no fun for her. 
Q: She stayed at the Sunshine Home for a while. Have you ever visited there? What's your impression?

LJ's mother: I went there once to take a look. (Laughing)

My impression was that people taking lessons there were much older. All of them were put into the same class instead of being separated into different classes. They could have made up two classes as far as I could tell. The teacher just gave some lessons. There wasn't exactly any curriculum. The teacher just talked about how to do things or how to behave, nothing serious.

Q: From your perspective, is there anything that the Sunshine Home should improve?

LJ's mother: From my perspective, I suggest that special education schools and the Sunshine Home teach more. I think the kids should learn more from books, because some of the kids are quite receptive to knowledge. But of course there are kids who don't learn well, especially if they are already of a certain age.

The kids should learn things they eventually will have to learn in life. For example, if you have learned certain Chinese characters, you will know how to take the bus and which stop to get off. Like my daughter, at least she knows which bus to take to which stop. If you don't know Chinese characters, you won't know where to go or where to get off. So learning Chinese characters is very important.

Q: So the kids should acquire more knowledge that is related to real life?

LJ's mother: Right, they have to because they will need the knowledge in real life. Math too. Calculations below 100 should be taught because they will need them in real life. For example, if you go grocery shopping, you should know how to buy and how to pay. You have to be able to do that. Like my daughter, she couldn't do it before. So I often gave her money and told her to go and buy groceries herself. How much does this cost and how much change should you get back? She learnt by constantly doing it.

Now I need to teach her how to calculate payment, like calculating how much to pay for vegetables of a certain price and certain weight. Now she only knows how to pay whatever the vendor tells her to pay, and she never thinks about how to calculate whether it's the right amount or not. It's easier for her to do what the vendor says, because it's more difficult for her than for us, you know, to do the calculation. In this regard, she is different from us. Calculations like this are not easy for her.

Q: So you mean that when she buys things, she pays whatever the vendor tells her to pay and brings back the change, but she doesn't know how to do the calculations?

LJ's mother: She knows how much change she is supposed to bring back, but she doesn't know how to calculate the amount she should pay based on the price and weight of a vegetable. She doesn't have that skill.

Q: You believe that she should be taught this kind of thing both at school and at home, right?

LJ's mother: Right, because the most basic skill is how to use money, don't you agree? The school didn't teach her that, like how to calculate how much to pay for a vegetable of a certain price and certain weight and how much change you should back. It might be too complicated to be taught anyway. 
Q: Our understanding is that the Sunshine Workshop pays into social insurances, not the Sunshine Home. So we want to confirm whether it was the Sunshine Home or the Sunshine Workshop LJ went to.

LJ's mother: Should be the Sunshine Home. As far as I can remember... right, there were no payments into her insurances when she was going there. Yes, the payments stopped. She went there after the supermarket was closed. It's located within an apartment complex with an entrance on Tongchuan Road. If you ask around, people in that neighborhood all know about it. Should be the Sunshine Home.

Q: Did the payments stop after LJ refused to go there, or were there no payments to begin with?

LJ's mother: There had never been any payments from the Sunshine Home.

\section{Good Rapport with Co-Workers}

\section{Q: How did LJ end up working at Papa John's?}

LJ's mother: I was worried about her being unemployed, so I asked a good friend for help. I said that my daughter had no job and just stayed at home. I didn't want to hide it from her, right? LJ is the kind of person who didn't do well academically, so I asked my friend to watch out for a job that might fit her. My friend said that she would do that.

It just so happened that Papa John's was hiring and my friend told me to take LJ for an interview, so I did. The store tested how good she was at kneading and tossing dough, and a couple of days later notified her to report for an internship.

Q: Did she start at D store? When did she sign the contract?

LJ's mother: She started at M store. Before 2010, there was a Special Olympics World Games and Papa John's was hiring. If I remember correctly, she was hired in 2010. Before 2010, there was a Special Olympics World Games in 2008. ${ }^{1}$ She participated with schoolteachers in a performance which was later made into a VCD.

Q: LJ participated in the Special Olympics World Games?

LJ's mother: She did, in a dance performance.

LJ's mother (asking LJ): What did you perform?

LJ (answering): Some artistic number, dancing actually. There were a lot of reporters.

LJ's mother: Oh, there were a lot of reporters. So she must still have been at school. I don't quite remember.

LJ: There were also a lot of celebrities.

LJ's mother: A lot of celebrities, is that right? So, she must still have been at school and not yet at Papa John's.

LJ's mother (asking LJ): When you joined Papa John's, did you sign the contract in 2008 or 2010 ?

LJ (replying): 2010. The first one I signed was for the internship.

\footnotetext{
${ }^{1}$ In 2007, Shanghai hosted the Special Olympics World Summer Games.
} 
LJ's mother: The contract was signed in 2010. Upon hiring, she signed a 3-month internship, followed by a 1-year contract. She has been working for a long time at Papa John's.

Q: During the internship, was there anyone teaching LJ?

LJ's mother: Someone had to teach her during the internship. Someone taught her how to knead and toss dough.

LJ's mother (asking LJ): When you first joined, you must have had someone teaching you, right?

LJ: Yeah, someone was teaching me.

Q: So how did that person treat her?

LJ's mother: Very nice. They all treated her nice at $M$ store, including the employees, store manager, and shift manager.

They saw her as a very cute little girl. My daughter was very social when she joined, she wasn't the mature kind. She was young, 19 going on 20, very naughty, and very cute, still like a little girl.

They all liked her, called her "little chubby" and treated her really nice. She did whatever they asked her to do and goofed around with them like a child. Sometimes a co-worker would ask her to work overtime and she would say, "Buy me a soda and I will do it." It was funny.

Q: So she knew how to bargain?

LJ's mother: Right. She would say, "Buy me a soda and I will work two extra hours." The co-worker was really nice and bought her a soda. It's very cute, I buy you food and you do things for me. She did well, getting along really well with people and with co-workers. She would buy food for others and share her food with them. She would say, "Let me buy you some drink." My daughter was really happy then, so was I.

At the end of the year, they would go out to eat to celebrate and sing karaoke. They would invite her to all the group activities, and she was happy, without a worry in the world. The two managers at M store were very nice to her and are still in contact even now. After that store was shut down, the two managers left Papa John's but are still close with LJ.

Q: You mean the two managers from $\mathrm{M}$ store?

LJ's mother: Yes, those two managers. They have remained friends with LJ and often take her out. After M store was shut down, one of the managers got a job at a coffee shop in Xujiahui. She runs the store and asked my daughter to go work there. I knew nothing about the store, so I didn't let her go. I was worried that the store was too far, being in Xujiahui. Now that I think about it, she should probably have gone to work in the coffee shop.

I figured back then that the job with Papa John's was relatively stable, so I didn't let LJ quit. She was still young and listened to me about not changing jobs. Now she definitely wouldn't agree with me! (Laughing)

That coffee shop stopped hiring later on, so LJ couldn't go there even if she wanted to. The pay was good there. I thought maybe the coffee shop job wouldn't be as stable, you know. But when I changed my mind, there were no openings anymore.

Q: What exactly does LJ do at Papa John's? 
LJ's mother: When she first joined, she was kneading and tossing dough. The pizza dough at Papa John's is all handmade. At first she didn't know what to do, so she received training and was also trained in laying the ingredients. After some time, after she had mastered the dough and the ingredients, she started learning about appetizers and now she can make everything. No one taught her later on. She was on her own, learning while watching how everything was done. It's a tough job kneading and tossing dough because it requires a lot of strength in your hands (See Fig. 1).

Q: So it requires a lot of elbow grease?

LJ's mother: Yes, it's really strenuous, because you have to put a lot of strength into your hands. So she joined and learnt a bit of this and a bit of that and ended up knowing everything.

Q: How long did she work at M store?

LJ's mother: Four years, which were four very happy years for her. Then she was transferred to D store where interpersonal relationships were more complicated and tough. Even before her transfer, the store was known for that.

After M store was shut down, the manager asked us to pick a store to transfer to. I wanted her to be somewhere close, so I didn't pick C store. I should have picked C store because it would have been easier to get along there.

Q: At Papa John's, how does she get along with her co-workers?

LJ's mother: She gets along okay. The managers at $\mathrm{M}$ store were so nice. After she got transferred to D store, there was an intern manager who was new. He was really young and seemed to look at people like LJ differently. He was always referring to them as "special". And LJ might think, "So what if I am special. That's no reason for you to always call me that." It just didn't sound nice.

The fact is that my daughter is just half a beat slower than ordinary people. She just couldn't do well academically, but she can learn everything else. She is a little overweight. But she isn't inferior in anything and she can do everything. Failing school has indeed affected her. If she had done better academically, she would be working at a less physically demanding job. There's nothing to do now without a degree. So she had a fight at D store.

Q: Fight? Fight with LJ?

LJ's mother: Didn't I tell you before? She had an incident at the store. Had a fight with them at the store, you know.

Q: For what reason?

LJ's mother: There was a time when they probably had some issue with her, because... I actually don't know what it was over.

She is very capable at work. My daughter isn't the subservient kind and she talks back if you say things that are not appropriate. She is in a position to do so, because whatever you ask her to do, be it in the dining area or in the kitchen area, she can do it. If the manager picks on her, she will talk back. I told her that she must have been driving the manager crazy.

If someone picks on her, with or without a good reason, she won't take it sometimes. There were people at the store who were condescending because they were some sort of manager. Like that time when the shift manager asked her to move things around. She did it the first time, and when she was asked to do it a second 


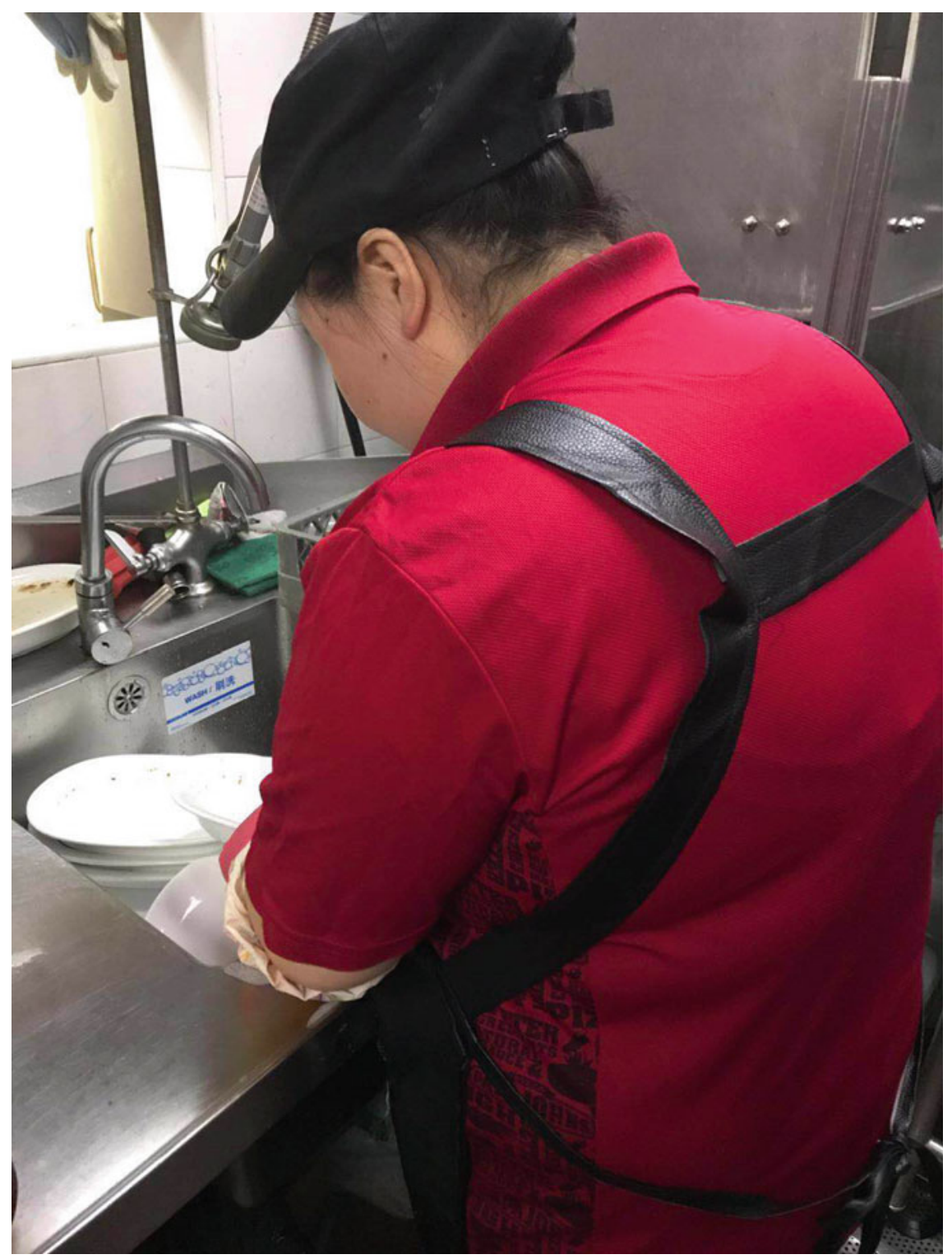

Fig. 1 Ms. LJ at work

time, she said, "Wait, I will do it later." My guess was that she didn't say it in a nice way.

Q: Because she was in the middle of something?

LJ's mother: Well, it was because she already did what she was asked to the first time. There were other people around with nothing to do, but she was the one being 
ordered to move things. After she complied the first time, she was ordered a second time. Moving things was not part of her job, so she didn't like it that she was being asked to do it a second time. She should have said, "Wait till I am done with the silverware I am wiping." Instead she told the manager to wait, and the manager didn't like it, thinking that she refused to follow orders.

So the shift manager told the store manager that LJ refused to listen to him, and without investigating into the matter, the store manager gave my daughter a tongue lashing. My daughter told me about it on the phone later. I asked her if she moved things like she was told to, and she said she ended up still doing it, you know.

The store manager told her that the shift manager was her leader and she must do whatever he told her to do. She asked for a chance to defend herself and the store manager told her to save it. That kind of attitude was very frustrating and made things worse, right?

Before the incident, the shift manager had always looked down on LJ. He treated her differently and called her "special". The store manager asked him to apologize for using this word, and LJ said she didn't need the apology but just hoped that he wouldn't call her that anymore because it didn't sound nice.

Q: LJ was told to apologize to him?

LJ's mother: No. After the fight, because the shift manager called her "special," the store manager didn't think it was appropriate, so he asked him to apologize to my daughter. My daughter said something like, "You don't need to apologize, just don't call me that anymore."

Q: So he was told to apologize to LJ?

LJ's mother: Right, because he had been calling her "special." My daughter said, "You don't have to apologize to me. Next time you see me, just don't call me that." Just don't use the word "special" because people know that if you are "special," you have a disability certificate, you know.

Q: The shift manager called her "special" implying that she has some kind of disability, and calling her "special" shows sympathy, right?

LJ's mother: No. By calling her "special," he was looking down on her. "Special" means having a disability certificate and someone who isn't normal and is inferior. You call ordinary people by their names. You don't just call someone "special."

Q: So he just called her "special" bluntly instead of addressing her by her name?

LJ's mother: Right. Calling someone "special" is very hurtful, because it's a word used for someone with a disability certificate. Society wants to show care for this group by calling them "special" but everyone knows what it really means. No one likes to hear it. Even if I do have a disability certificate, I wouldn't be happy if you kept calling me "special."

So the store manager called the district manager and the district manager suspended her job. The fight happened at work on October 2, and she was told the next day not to report to work anymore. I didn't know exactly what happened except that her job was suspended. I figured so what. There wasn't a resolution until the end of October, then she was transferred to $\mathrm{W}$ store on November 1.

Q: So she isn't at D store now?

LJ's mother: No. She is at W store now. 
Q: Did LJ ask for the transfer herself or was it arranged by management?

LJ's mother: Management transferred her to W store, and the district manager was actually the one handling transfers. The district manager for $\mathrm{D}$ store was in a dilemma not knowing whether he should let LJ stay or leave. I could have had LJ stay back then, but it wasn't necessary, because after the fight, it wasn't fun for her to stay there anymore. I mean we could have insisted on not leaving, but that would have put the district manager in a difficult position.

The store manager should have been the one to get transferred. If I had refused to budge, the store manager would have had a hard time, you know. But I compromised once the district manager got involved, and it was an easy out for everyone involved.

Q: How long did LJ work at D store?

LJ's mother: She worked at D store for 3 years and at Papa John's for a total of 7 years. She got transferred from M store to D store in 2013 and stayed till 2016, so 3 years it was.

W store is pretty far now and she spends more than an hour commuting. When she was working at D store, she could bike to work. Now she needs to take two subway lines and one bus, which costs more. Closer is always better, because it's more convenient.

After she got transferred to $\mathrm{W}$ store, she has to leave for work really early in the morning in winter to catch the subway. You have no idea how crowded Line 7 is at 8:30 a.m., and Line 2 is no better. So she has to leave for work early and doesn't get home till pretty late. It takes time to change out of her work clothes, and there's a delay of 10 min changing from one subway line to another and a total of $20 \mathrm{~min}$ or so waiting for the transportation. So it takes a long time to commute to $\mathrm{W}$ store, and she can't work overtime for more than $30 \mathrm{~min}$.

Q: Does she work morning shift or evening shift?

LJ's mother: She works mostly afternoon shift, which starts at either 10:30 or 11 a.m. and lasts till 8 p.m. When they get busy sometimes, the shift extends to 9 p.m. She can't work any later than that because there will be no bus. It would have been better if she just needed to take one subway or one bus. It's too much trouble transferring from one to another. So I don't want her to work too late because we live far from work and I would worry about her getting home very late at night.

Q: Have you ever visited her at work after she got transferred to W store?

LJ's mother: I went with her when she first reported for work.

Q: What's her work schedule like now? How many workdays and how many off days?

LJ's mother: She works 5 days a week and gets 2 days off. The policy of the store is that she can take days off between Monday through Friday when the store isn't busy so that she is guaranteed 2 days off. Sometimes she takes Monday off, sometimes Tuesday off, and she normally doesn't get two consecutive days off. For example, she will take today off and then another day off after a day or several days.

Her job is actually very arduous and she puts a lot into it. Not many people know about it, but the store has been lowering the pay without really announcing it. During Chinese New Year last year, she worked overtime for 7 days straight, starting with New Year's Day. I asked her how much she got paid for the overtime and she said 
not much. She was promised overtime pay but the take-home amount was pathetic. I don't know how the store calculated this. She has never taken time off during Chinese New Year. Employees of the store who are from other provinces went back to their hometowns, and she stayed behind to work. Last year, she worked so hard during Chinese New Year. She went to work every single day. But now the pay is dwindling.

Q: Dwindling?

LJ's mother: Right. Isn't there supposed to be a pay raise every year? But her pay just remains the same. We get a pay raise every year, but at her workplace, her pay hovers around 2,100 or 2,200 yuan. We get at least 2,500 yuan every month, how come she gets less than I do? The pay isn't enough, and I keep thinking that she should be given the opportunity to work more and to get paid more, because what can she do with so little money?

Q: Have you ever looked into why it is like this?

LJ's mother: Papa John's looks okay for those not in the know, but it has its own books to keep. Some stores don't make money, so the company has to balance everything. Once she has worked a certain number of hours every month, she won't be allowed to work anymore, which is kind of mean. The store counts her work hours as six per day. There is a long break during the day, but she can't very well go home and has to stay at the store. She should be working $8 \mathrm{~h}$ a day but is allowed only 6 or $7 \mathrm{~h}$. I ask her whether she has worked the hours she is supposed to work, otherwise the store will deduct from her pay. I just think she should be allowed to work more hours, otherwise she will have to make do with minimum pay.

I don't know how her pay is calculated now. Under the contract, it was 1,800 yuan which was increased to 2,000 and then 2,200 yuan later. Nothing happened this year, even though there should be a pay raise every year. I don't know if her workplace follows this practice. I am not talking about my own workplace. Workplaces like hers normally pay three social insurances for the employees, but her workplace only pays two insurances. The money is really next to nothing. She should be allowed to work more. She is young and can work more, right? So she should have the chance to work more.

Q: Work more?

LJ's mother: Work more for more pay. She gets paid too little and doesn't have enough to spend. She wants to work more and make more money. Now she is only allowed to work so many hours but still has to go to work 5 days a week. On those 2 days off, she can't exactly work another job. The best she can do is some temp work paying 18 yuan an hour, which she tried for a while.

Q: LJ did temp work?

LJ's mother: Yes, she did, on that street over there with lots of restaurants. I told her back then to work hard and she said she knew and she would work hard.

Q: What did she do for the temp work?

LJ's mother: It was restaurant work and there are all sorts of things to do at restaurants. Because she knows how to make appetizers, she found a job doing this and it came with good pay. But I wasn't sure whether it could turn into a long-term job and what if she quit Papa John's and ended up with a place that didn't pay social 
insurances. That would not have been good, you know. You shouldn't just quit a job without knowing what you are getting into.

I don't know how to raise this with Papa John's. She would like to work more hours and make more money. She is actually already busy as is and the job gets tiring. Friday, Saturday, and Wednesday are the three busiest days. There are endless customers and endless things to do at the store, and no one can take any break.

Q: No break?

LJ's mother: No break during peak hours. The only break is for her to eat. People like her work really hard and don't get much of a pay raise, unlike at other workplaces. She gets paid 2,000, 2,100, 2,200 yuan, and I don't know how she is going to be able to live on that. Everything is so expensive now and prices keep going up. Once we are too old to help, I don't know who she can depend on for a living.

Q: While I was observing her at work at W store, I felt that she gets along very well with her co-workers. LJ is a conscientious worker, and she jokes with other employees in the store. Does she come back and share with you what happens at $\mathrm{W}$ store?

LJ's mother: Not a lot, because she comes home late, between 9:30 and 10 p.m. on most nights. But she does share sometimes, like it got so busy at the store, there's an older co-worker whom she can bond with, or the store got a new manager who is nice, isn't condescending like some other people and doesn't look down on her.

Even though she has a disability certificate, co-workers at this store do not look at her differently, and that's what's making her happiest.

Q: Did anything happen that impressed you most after LJ started working? I mean something that is very memorable, or a little surprising or touching?

LJ's mother: After she started working, as she grows older, she has become more caring, especially over the last several years, really. I am getting older, so when she sees me tired from work or not feeling well, she takes good care of me. When I got sick or hospitalized or had to get IV treatment, she was at my bedside caring for me. She is a very good kid, really good kid.

Q: She does things for you?

LJ's mother: Yes, she does. When I have a headache sometimes, she would cook me porridge and tell me, "Mom, I know you have a headache. Let me put a hot towel on your forehead, and let's not take any medicine." She would search on the computer for information on headaches.

Q: She does that?

LJ's mother: Yes. She told me not to take medication. When I have a headache, I can usually relieve it by putting a hot towel on my forehead. That's what she told me. I suffer really bad from headaches sometimes and would throw up. She would clean up after me and cook porridge for me. She is really good and takes good care of me.

Q: Did you see any changes in her after she started working?

LJ's mother: She has become more open. She had no job for a while. You know, after the supermarket was closed, she stayed home for 6 months and seldom went out. Just stayed home playing computer games and didn't talk much to anyone. After she joined Papa John's, she has changed a lot. Because she interacts with a lot of 
people, she has become more open and gets along very well with everyone. She finds herself in all sorts of situations, which helps her handle things. After all, she works in the service industry, so she has to be able to interact with people, to face issues and to vocalize.

\section{Dependence on Mom}

Q: Can you talk about LJ in everyday life? Does she lend you a hand around the house?

LJ's mother: She gets lazy at home and isn't eager to help.

Q: But based on my observation, she is a conscientious employee.

LJ's mother: I think she just doesn't want to do anything at home. She gets super lazy and just lies around the house asking me to do everything for her.

Q: Does she clean the house or cook?

LJ's mother: She knows how to do it, but she is really lazy and won't do it. On her 2 days off, she has nothing to do. With me around, she is too lazy to do anything, because she knows that Mom will cook for her and she won't have to do it herself, you know.

The fact is that she can do all of those things, but she won't do any of it. She just wants to play on the computer, as you can see for yourself, even though she keeps telling me to go out and have fun for myself. If you ask her to cook, do laundry, or clean the house, she can do all of it. But she likes to depend on other people and prefers that someone do it for her, like laundry and cooking. I figure that her job is tough, from morning till night, so I spoil her by doing most things for her. I ask her what will happen when I can't do anything for her anymore, and she says she will figure it out when the time comes.

Q: She has the ability to help around the house, but she won't do it because she prefers to depend on her parents, right?

LJ's mother: Right, she wants me to do everything and hand it to her while she lies there resting. She likes to depend on me even though she knows how to do everything. I see her already overweight and gaining more weight, and she won't do anything to keep the weight off. But I can't make her do things she is unwilling to do. Girls nowadays are like that. My co-worker's daughter is the same. I asked her if her daughter helps around the house and she said that her daughter doesn't lift a finger. I said, "Same here. I have to do everything like cooking. I get so busy, but my daughter hardly ever helps."

But sometimes she does deposit money into my bankcard and pay my credit card bills. And sometimes she would do laundry and wipe the floor. Occasionally she would cook.

Q: What does she cook?

LJ's mother: Simple dishes, and all vegetarian. Tomatoes with eggs, shredded potatoes, simple ones. She can't cook meat yet. She cooked fish once and didn't like 
what she cooked, and she didn't cook meat well either. If she is alone at home, she won't starve herself.

Q: Has she ever done anything in everyday life that surprised you? Something you didn't think she could do but she ended up doing very well.

LJ's mother: Nothing she did was unusual and I didn't think much of anything. When she was young, one time she washed her sneakers really thoroughly. I couldn't have washed them so clean myself. I looked at the sneakers and was amazed at how clean they were, and she was still going to school back then.

She is actually quite capable herself. She is very neat and has to wash her own clothes and work clothes separately. She never mixes them together. Every day when she comes home, she will put her work clothes in the washer.

$\mathrm{Q}$ : She comes home late, so you will have dinner ready for her. After she is done eating, will she help you clean up?

LJ's mother: She won't if she is tired. Actually, she doesn't eat much rice for dinner. She would pick from the dishes that I have cooked followed by some fruit. If she is really hungry, she will have some rice, or if the dishes are very good, she will eat rice to go with them. After she is done eating, she won't wash the dishes. She will just change, take a shower or wash her feet. She gets really tired sometimes.

She works in the kitchen area all the time now and it gets really hot with all the ovens on. Like the last couple of days, the sweat kept dripping down and she had to keep wiping it off with a towel. I told her to keep hydrated. She comes home tired, so she needs to rest a little before showering. Sometimes she is too tired to shower.

Q: Does LJ talk to you or your husband often? What does she talk about?

LJ's mother: She does talk, about work, about friends, about everything. We all get busy, so we only talk occasionally. She gets home from work late, 9 or 10 p.m., so there isn't much time to talk. I work too, and my hours are different from hers. And we eat at different hours. It's not often that we are all home together and can sit down to eat together. So she doesn't have a lot of time to talk or communicate with me.

She sleeps late every morning and usually gets up at 10 a.m. I get up early and fix her breakfast. She eats the breakfast and immediately leaves for work. If I have a morning shift myself, I will have to leave for work at 6 a.m. and won't get off till 6 p.m. I will have finished dinner before she comes home. That's how it is.

Q: What about the weekend? She should be able to spend more time at home over the weekend.

LJ's mother: We take different days off. I work 2 days and take the next 2 days off. On some of her days off, I have to work. And on some of my days off, she has to work. We may not always be able to spend time together.

\section{Ordinary People for Friends}

Q: Did LJ like to interact with strangers when she was young? Like playing with kids she didn't know. 
LJ's mother: She seldom interacted with kids she didn't know and only played with those she knew. She needed some time to get to know strangers before playing with them.

Q: What about now? Will she say "hi" to people first?

LJ's mother: It depends. At the new workplace, she will go up to people and say "hi." And she knows how to handle interpersonal relationships.

Q: So you see her changing as she grows older, right?

LJ's mother: Right. She was different when she was young. When she was young, she seldom played with kids she didn't know. As she grows older, she has become more open and more mature intellectually, right? Because she is older, she thinks more than when she was young. She has been working for many years in the real world, I think 6 or 7 years. She has gained a lot of social experience and has certain social savvy now, unlike when she was staying home all day.

Q: Of her co-workers and friends, some are like her and some are ordinary people without disability, right?

LJ's mother: Right. Most of the people she interacts with are ordinary people. She doesn't really hang out with people with disability certificates. Some people she knows are college students with really high IQs. When she goes out with friends, it is with ordinary people too.

Q: So she doesn't interact with people with ID?

LJ's mother: Very seldom. After graduation, the kids went their separate ways. There were two best friends, but she lost their phone numbers and couldn't get in touch anymore.

You don't see many people like her out there now. And even at Papa John's stores, there are not many of them. I believe there is a mute employee, and another one... well, just two or three of them. She works alongside them, but seldom goes out with them. Working and hanging out are separate.

Q: How did LJ meet those friends from the real world?

LJ's mother: Some of them are college students who interned at the store, and the others are friends of friends from the store. They went out together and got to know each other.

Q: Does LJ make friends online?

LJ's mother: Not online, she doesn't try to make friends online. She only makes friends with people she knows, not with strangers.

Q: Does she ask friends out?

LJ's mother: She does invite friends to eat out or shop. She likes to go out with friends whenever she has time off. As you can see, I don't bother her and I hardly ever go shopping with her, because she has her own circle. Her friends are all married. She knows how to have fun, and only stays home now because of the problem with her leg.

Q: So she goes out a lot with friends?

LJ's mother: Definitely. She goes out a lot with friends. Last time she went with friends to Huang Mountain in Anhui. On the day she left, she was supposed to take the 8:20 a.m. high-speed train. I asked her if she knew how to get to South Train Station and she said she knew. She packed her own suitcase and organized clothes 
and toiletry. I took her to the train station and asked her if she had got her train ticket. She said she had and told me where she should wait for the train. It was close to ticket inspection time and 8 min till boarding, and she listed to me all the things she was supposed to do. Then she boarded, and everything looked good.

She likes to travel too. Last year she went to Hangzhou for 5 days, and this time she took 5 days off just to travel. She spends a lot of my money every time. When she went to Huang Mountain, she said she didn't have enough money, so I gave her 2,000 yuan. When she came back, I asked her how much she had spent and she said over 1,000 , actually over 1,800 yuan. And I said, "As long as you had fun."

At that time, there was a manager she was pretty close to. The manager had money and offered to pay for her. I told LJ not to let her do it and she said she knew and that she wouldn't let another person pay for her travel. It's okay to let another person pay for small things like snacks, but you shouldn't ask anyone to cover your travel expenses, however rich that person is. You should pay your share no matter how much it is, and having fun is the most important thing.

My daughter likes to buy things and the manager bought things sometimes and would offer to pay for her. I told LJ, "Wherever you go, just pay whatever you need to pay." The train ticket was bought online. They joined a local tour group upon arrival and paid entrance fees at the tourist spots. They went Dutch all the time, including meals.

Q: Do you remember the first time she went traveling without you?

LJ's mother: It was the year before last. Before that, she had never been out without me. The year before last, she went out with friends, not on her own, to Qibao, for a beauty bath on Old Street. They knew each other well and used to hang out a lot. They spent one night in Qibao.

Q: The Qibao trip was, after all, the first time she went out with friends. Were you worried?

LJ's mother: I was a little worried, because she was spending the night away from home. And she is a girl. I had asked her who she was going out with. But she wouldn't go out with guys and would only spend the night with girls. But I didn't over think. She did come back okay and she came back on her own.

She normally goes out with people who have decent jobs, like she went out twice with the managers of the store. Or she goes out with young people like college students. She only goes out with people she has known for a while, never with strangers.

Q: When she goes out, will you call her and ask how everything is?

LJ's mother: I don't call. We just message each other.

Q: When she goes out, will she update you on her whereabouts?

LJ's mother: She will. WeChat has voicemail function, right? So we use that. She has been using WeChat, cell phone, and computer for a long time. We had a laptop around the time she graduated, then we bought a desktop which cost more than 4,000 yuan. She learnt to use the desktop a long time ago. As for the cell phone, I bought it for her when she was working at the supermarket. I didn't buy her a phone when she was still going to school. After she started working, I bought one for her and she 
immediately learned how to use it. Cell phones are no big deal, just something for her to play with, right?

Q: Do you still travel as a family now?

LJ's mother: Not now. She doesn't travel much with us. Before, I took her traveling all the time, and as recent as 2 years ago, she still went with me to Hangzhou and Suzhou, and we traveled with tour groups too. Now she just travels with friends, not me.

My daughter has no problem socializing. The only thing is that she wasn't good academically and is actually slow, definitely slower than ordinary people like us, and there's nothing I can do about that. And she can't cover every angle when handling problems, and when she talks, she isn't politically correct like some other people. Those people know how to talk to make you feel good.

People like her are straight shooters. Her temperament is such that when she is unhappy, she will vent. What can I do? That's just her way. People like her are simple and straightforward when speaking or doing things. They don't beat around the bush or act sneaky. She shows it whether she is happy or unhappy. The conventional wisdom is that you should keep something to yourself, but she doesn't because people like her can't keep anything to themselves. So when she is with friends, their interactions are very simple.

\section{Bittersweet Emotional Life}

Q: Now that LJ has grown up, has marriage ever come up in any discussions?

LJ's mother: It has. I figure that she isn't getting any younger, so it would be ideal for her to have her own life and be independent.

It would be nice if she could have her own family and someone to take care of her. I would feel much better. We are getting old and can't be with her forever. I will have peace of mind if she gets married, otherwise I will keep worrying about it.

Q: Has anyone tried matchmaking for her?

LJ's mother: She has a friend, a girl who is pretty close to her. She introduced someone to her a while back. That guy doesn't have any disabilities. They went out for a while but it didn't lead anywhere.

Q: How long were they together?

LJ's mother: Pretty long. More than 6 months.

LJ's mother (asking LJ): The one you dated before, how long were you together? The one who worked at VW.

LJ: One year.

LJ's mother: So they dated for about a year.

$\mathrm{Q}$ : One year is kind of long. When they were together, did you ever observe his attitude towards LJ?

LJ's mother: Looking back, I think he treated her nice. But he wasn't committed. He was probably looking for someone better, you know. 
Q: He thinks because he doesn't have any disabilities, he should look for someone better?

LJ's mother: It's not that. He didn't know about my daughter's disability. He is from Shanghai and a decent family, so he was probably looking for someone with a better background. As soon as I learnt that one of his parents is a doctor and the other is a teacher, I figured that our own family background didn't exactly match his. There seemed to be a little gap since his family isn't blue collar. I didn't really mind it and decided just to let things run their own course. But later on, behind my daughter's back, that guy found another date, you know. He was meeting with another girl, and my daughter happened to see it with her own eyes. She was shopping with her co-worker and in the same restaurant, she saw him eating with another girl.

My daughter was serious about the relationship, but he didn't seem to be. So you can imagine how maddening it was. After a while, that guy wanted to get back with her and she didn't agree. I was kept in the dark for a while. She told me some time later when I asked her about it.

Q: So she didn't tell you about it when it first happened?

LJ's mother: Right. After a while, after she had calmed down, she told me bit by bit. She needed time to lick her wounds and to recover. She was hurt and she took it upon herself to heal. It didn't take very long and I didn't exactly keep track. I didn't know that kind of thing had happened between them, because what's the point of always checking. They had seemed to be fine. Then I asked her one day how everything was, and that's when she told me.

Q: While she was dating, she was also working. How did she balance work and dating?

LJ's mother: Right, she was working then. Work is work and she was doing well at work, because dating can't be allowed to affect work. They only went out on her days off. Sometimes she would get off work at 10 or 11 p.m., and he would pick her up and bring her back. Young people like to eat out late and she is no exception, so they would go out to eat very late at night. That guy was okay, according to my daughter. I have never met him myself. I just heard about him from my daughter. They had just started dating and I couldn't very well ask to meet him. I would have asked to meet him if the relationship had become serious. That's why I never got the chance to meet him. And I never dealt with his family either. There was no need, was there?

Q: Have you and your husband ever thought about what kind of plan you have for LJ since you are getting old yourselves?

LJ's mother: We just want her to find a good boyfriend so that she can have the other half to take care of her. The guy doesn't have to come from a fancy family. Average is good enough because that's what our family is. The important thing is that the two of them can talk and can take care of each other.

She has to find someone, right? Because we are getting old and fragile and won't be able to take care of her in the future. So we hope that there will be someone to marry her and they can take care of each other.

$\mathrm{Q}$ : Does the guy have to be someone without disabilities? 
LJ's mother: That would be ideal. It doesn't matter if he is lacking in some other areas, but it would be best if he doesn't have disabilities.

Q: Does he have to be from Shanghai?

LJ's mother: He should be from Shanghai or at least have an apartment in Shanghai. They won't be able to buy anything, so if they can get married with a place to stay already, that would be nice. I don't want them to have kids, because what if the kids have problems? So I think it's better for them not to have kids. They should just take care of each other, that's the best way.

(At the time of the first interview with LJ's mother, LJ wasn't exactly in a relationship. By the time of the second interview, LJ was already dating.)

Q: When I interviewed LJ at Papa John's the other day, she had takeout for lunch and said that her boyfriend ordered the takeout for her the night before. Do you know her current boyfriend?

LJ's mother: Yes, I know him. He probably ordered the takeout ahead of time and had it delivered on the day. I have met with the guy. He doesn't talk much and isn't the bubbly kind. They were co-workers at D store and had known each other well before dating.

Q: You mean the store that LJ left?

LJ's mother: Yes, D store that LJ used to work at. They worked together there, then LJ got transferred to W store and he stayed on at D store. They knew each other from working together, then the guy probably approached her, then they started dating.

Q: So LJ met her current boyfriend at D store and started dating him back then?

LJ's mother: Yes, they met and started dating when they both worked at D store.

Q: Did LJ get transferred to W store because of the relationship?

LJ's mother: No, it wasn't because of that. The transfer was work-related. That store was giving my daughter a hard time at work and had never really liked her. Even though my daughter has a disability certificate, she isn't one to be easily bullied.

Q: How does LJ's current boyfriend impress you, the way he does things? You just mentioned that he isn't bubbly or talkative, so what's he like in his actions?

LJ's mother: In his actions, I don't think he is a very proactive person. He will do whatever you tell him. He doesn't like to talk, but he knows.

Q: Have the two families met yet?

LJ's mother: Not yet. In fact, the two kids have been to each other's place and met with parents on the other side. But we haven't met with his parents, because that would have implied discussions of marriage. We are not there yet.

Q: Do you have any expectations in that regard?

LJ's mother: I did ask them once, and they said that they would start discussing it after Chinese New Year and that parents on both sides should get involved in the wedding planning. Now I am not sure what's going on. They won't tell me and I can't very well ask.

My daughter is already 27 and not young anymore. She can hardly afford to wait one or two more years. I prefer it simple and won't really ask much from the guy's side. Just plan a decent wedding and I will pay my share. If the guy's family has money issues, we will just keep it simple and not do what other families do. It won't 
be necessary and I actually prefer not to have a fancy wedding. As long as the two kids are okay with the plan and can live happily ever after, I have no complaints.

The guy is 3 years older than my daughter. Even though he is quiet, he is a nice person. Sometimes when my daughter isn't feeling well, he will take her to the doctor and take care of her. You won't have to tell him to do that. He will do it himself, so that's what I like about him.

Q: Do they spend a lot of time together?

LJ's mother: They hardly ever have the same days off and it's not easy for them to get together. Right now, if he works evening shift and my daughter has that day off, they can meet for dinner. If he works morning shift and gets off at 4:30 p.m. while my daughter gets off work late, then they won't be able to meet. Her shift starts at 11 a.m., so she leaves for work at 8:30 or 9 a.m. and gets back at 9 or 10 p.m. As you can see, she hardly has time for anything outside work. On her days off, she wants to go out and shop. So the two of them don't get to meet unless the guy works morning or evening shift on my daughter's day off.

Q: So basically they can meet once or twice a week, right?

LJ's mother: Yes, they can. He lives close by, on Xingzhi Road, so it's convenient.

\section{Expectations for a Better Life}

Q: After LJ got the disability certificate, what kind of benefits has she been receiving?

LJ's mother: The district DPF used to sponsor an annual physical. She got a physical at a hospital twice, but there's no such benefit anymore.

Q: Is there any subsidy?

LJ's mother: Minimum. Last time the DPF was giving out some money and I picked it up, 400 yuan if I remember correctly. So that's one time. They won't tell us what the money is for. They just notify us to go pick it up, and it's not a lot, about 200 or 300 yuan every year.

Q: The DPF seems to subsidize those with disability certificates each year. You've only received a subsidy several times?

LJ's mother: There's no subsidy for people like LJ who receive payments into social insurances. There's a certain amount of subsidy for those who have applied to receive 500 yuan per month.

After I got LJ the disability certificate at the district DPF, I was given two options. One was to receive subsidy each month and the other was to have the district DPF pay into LJ's health insurance and pension. I was thinking long term. A monthly 500 yuan might help in the short run, but what about the future, so I didn't apply for that money. I chose the insurance payments for her own sake. I wanted her to go out to work instead of staying home and waiting for this money every month. I couldn't allow her to think that she wouldn't have to go out to work since she had this money.

Q: What other expectations do you have for LJ?

LJ's mother: I just want her to live independently. I want her to handle her own issues whether they are social or individual, instead of asking me to handle them for 
her. She needs to face them herself and to find solutions. I also hope that she can find someone she can talk to and get married soon. It would be ideal when they can be together to take care of each other.

$\mathrm{Q}$ : Based on the interviews, I understand that $\mathrm{LJ}$ can handle things herself at work, which means that she can complete a day's work on her own. She goes out with friends on her days off and has her own social circle. Does she arrange her own daily life like what to eat and what to wear? How capable is she of living independently?

LJ's mother: She is just lazy. She wants to sleep late in the morning. She starts work at 10 a.m. and she will sleep till 9 a.m. And she stays up late at night. I told her to go to bed earlier, you know, and she isn't good about this.

She decides what to eat and what to wear most of the time. At home, she just eats whatever I cook. When she goes out, she decides what to buy to eat and to wear.

Q: What expectations do you have for your family's future?

LJ's mother: I just expect a normal life for the family. Of course, I hope for a better life and a higher level of living, and hope that my kid will do well. No big dreams. Another hope I have is that she can get to work more. Ordinary salary workers like us have no fancy aspirations. I just want her to have a stable job.

Q: Do you have any expectations for society as a whole?

LJ's mother: If you ask about society, I just hope that she can get a better job. I do have this idea about her switching to another place with better compensation, but I am not sure how workplaces will look at people like her. I am talking about a workplace which pays its employees better and offers jobs that she can do. With her disability certificate, I am not sure if her employment record is the same as ours.

If her employment record is different, once she hands it in, I am not sure if the workplace will take her, you know. It could become an issue, so I can't just let her switch jobs. I just hope that more workplaces will hire people like her. She is actually quite capable, so I hope there's a workplace that won't discriminate against her and will hire her. Our expectations are very low. We just hope that the workplace will pay her social insurances.

Q: She doesn't receive insurance payments now?

LJ's mother: Right now, she receives payments into pension and health insurance. I am not sure about unemployment insurance. The norm is to pay into four insurances, so paying into two insurances is the bare minimum. I didn't check with her workplace whether it is paying into unemployment insurance. I know for sure it is paying into pension and health insurance as it is the law. Everyone gets sick, and I know that there's deposit into the insurance card every month and every year. I know how much deposit there is into the pension too since I receive annual statements. I just don't know whether her workplace pays into unemployment insurance.

I hope that people like LJ are treated better, and that other companies in the real world won't look at them with different eyes. If she has the ability, let her show it, right? People always aspire for better. If you have the ability to make more money, who doesn't want to do it, because it makes your life better and happier.

...If she has to hand in the employment record, what I worry most about is what the hiring managers or workplaces will think if they see on the record that she has a disability certificate. 
Q: So you are worried that the hiring managers or workplaces won't accept LJ?

LJ's mother: Right, I am worried that they won't accept people like LJ. The fact is that she can do everything and is a conscientious worker. So I hope that more companies will accept people like her who do have the abilities.

Q: As far as we know, since LJ signed a contract with Papa John's, she is a fulltime employee eligible for the same benefits as all other employees. Papa John's is required by law to pay into five social insurances. You mentioned health insurance, pension and unemployment insurance. There are also maternity insurance and workrelated injury insurance. Housing fund is optional. So I wonder if you have checked with Papa John's on this?

LJ's mother: She should receive the same benefits as other employees. I remember her getting paid for three insurances which are health insurance, pension and probably unemployment insurance, but I have never really checked with anyone.

She doesn't receive housing fund statements and has never told me that she has those. For pension, she does get statements. And I am positive about payments into health insurance and pension. I am not sure about unemployment insurance, and I haven't heard anything about maternity insurance or work-related injury insurance.

Under the law, people who get minimum insurance coverage are women aged 40 and older and men aged 50 and older who have lost their jobs, and even those people receive payments into three insurances. So the minimum for $\mathrm{LJ}$ should be three insurances. As for the housing fund, I know it's supposed to be optional, but most workplaces pay into it now. I just don't know what the deal is with her workplace, and I can't really tell from the contract. The three insurances are required by the state, but I doubt her workplace will pay into the housing fund. I will look into it when I have the time and see if I can get some answers.

\section{Interview with LJ's Co-Worker (I)}

Interviewee: Manager Li (LJ's co-worker)

Interviewer and writer: Zhen Wei

Interview date: March 18, 2017

Interview place: Second floor dining area at the restaurant where LJ works

Notes on the interview: Manager Li supervised the kitchen and dining area and had been busy because it was the weekend. During the morning break, he had to go out and was unavailable for an interview. Customer traffic was getting heavier in the afternoon and Manager Li had been kept busy. As the interviewer had to leave at 8:30 p.m. and he had to work till 10 p.m., Manager Li decided to squeeze in the interview in the afternoon during a lull in customer traffic, which the interviewer really appreciated. Also, since LJ got transferred to $\mathrm{W}$ store only a short while ago and just came back from 1 month's sick leave due to sickness and a leg injury, Manager Li and other employees of the store had actually been interacting with LJ for only about 3 months. 
Q: Hello Manager Li, thank you very much for accepting my interview. I mainly want to know what LJ is like at work. What exactly are her job responsibilities at the restaurant?

Manager Li: Even though she is an employee being cared for, she is quite capable at work. She is a bit slow, but I think that's to be expected of all employees being cared for. You must have seen for yourself today, she has quite a few responsibilities, which isn't easy for an employee being cared for. She knows her way around the kitchen and can work at any vacant position there.

Q: Yes, that's what I have witnessed. How would you characterize her at work?

Manager Li: She is like a child at work. You saw for yourself that she would do some things out of context like talking to herself or trying to get attention like a little girl, but none of that affects her work.

Q: You just mentioned that LJ does a good job in the kitchen. Does she have the chance to interact with customers on a daily basis?

Manager Li: She interacted with customers at the other store. But you can see for yourself, her weight... Working in our dining area requires going up and down the stairs, otherwise she could have been interacting with the customers.

Q: You mean she can interact with customers, but out of consideration for her current physical condition, she works mainly in the kitchen, right?

Manager Li: Right, she had a leg injury a while back.

Q: When she fell?

Manager Li: Right, and she took about a month off. So I would rather not have her... the dining area isn't really that roomy.

Q: Have you ever seen her interact with customers? Will she approach the customers herself?

Manager Li: She doesn't take the initiative to communicate with them, but she can handle regular service processes.

$\mathrm{Q}$ : By regular processes, you mean that when customers come, she can take orders?

Manager Li: Right, she will go to take orders and ask what the customers might need. She can do things like that.

Q: What kind of personality do you think she has?

Manager Li: Personality wise, I feel that her mind is of a smaller capacity than that of ordinary people.

Q: Smaller capacity?

Manager Li: Well, not exactly that. I just feel that when she does things, she is like a child sometimes. But she isn't like that when interacting with people. She is actually pretty smart in that regard, just like ordinary people like us.

Q: How does LJ get along with her co-workers?

Manager Li: She gets along very well with everyone. We call her nicknames meaning little girl. She is pretty cute and everyone likes her because she is like a child.

Q: I know that she only joined the store recently. After work, is there any interaction with her? 
Manager Li: You mean between LJ and us?

Q: Right, among the co-workers.

Manager Li: In my own case, I don't interact with the store after work. I just want to keep work separate. I am not sure about her. But she normally gets off work earlier than I do, so I have seen her chatting on the phone with co-workers.

Q: Great. Thank you for squeezing in this interview and giving us so much information.

Manager Li: You are welcome.

\title{
Interview with LJ's Co-Worker (II)
}

\author{
Interviewee: Mr. Jiang (LJ's co-worker)
}

Interviewer and writer: Zhen Wei

Interview date: March 18, 2017

Interview place: Second floor kitchen area at the restaurant where LJ works.

Note on the interview: The interviewer was observing the kitchen area, which wasn't busy as there were not many customers. Mr. Jiang worked afternoon shift partnering with LJ. He kneaded and tossed pizza dough while LJ spread the ketchup and ingredients. They worked well together making pizza. Seeing a break, the interviewer asked Mr. Jiang if he was willing to be interviewed. He asked how long it would take and the interviewer said it would just be small talk, so he happily agreed. We thank Mr. Jiang for the interview.

$\mathrm{Q}$ : What kind of girl do you think LJ is?

Mr. Jiang: I think she is very kind and very mild. (Laughing)

Q: Can you give me an example?

Mr. Jiang: She is very nice to co-workers and dedicated to her work. After she has done her own job, she will take on something extra.

Q: How does she get along with you and everyone else?

Mr. Jiang: Very well.

Q: What makes you say so?

Mr. Jiang: You are referring to getting along or not?

(Interviewer nodding)

Mr. Jiang: She does get along very well with co-workers and has never fought with anyone. Never. She is always smiling and looks very mild. And everyone feels comfortable joking with her, so all is good.

Q: Yes, she does smile a lot. Thank you, Mr. Jiang.

Mr. Jiang: You are welcome. 


\section{Interview with Ms. LJ}

Interviewee: Ms. LJ

Interviewer and writer: Zhen Wei

Interview date: March 18, 2017

Interview place: Second floor dining area at the restaurant where LJ works

Note on the interview: This interview was conducted after LJ had her lunch. She was supposed to take a break after lunch, but happily agreed to the interview once the interviewer explained to her what the interview was for. Her work had been strenuous in the morning, but she cooperated well during the interview. After the interview, she only had 10 min left of her break, so she took a catnap with her elbows on the table before getting up to prepare for afternoon work. We thank LJ for the interview.

Q: Which school did you graduate from?

LJ: Graduated from? It's a vocational school.

$\mathrm{Q}$ : Do you remember the name of the school?

LJ: It's called Gan Ning.

Q: Was the school far from where you lived?

LJ: No, I could bike there.

Q: So you biked to school?

LJ: Right.

Q: Do you remember how long it has been since you graduated?

LJ: Maybe 3 years. It's been 2 or 3 years since I graduated.

$\mathrm{Q}:$ Do you remember anything from school?

LJ: Not really.

Q: When I interviewed your mom earlier, she said that you really liked Ms. Zhang. Is that true?

LJ: Yes, the Ms. Zhang who used to live next to us. But we are not in touch now, because I lost my phone and couldn't find her number. If I run into her on my way to work or back home, I would say "hi" to her and she would ask me how everything is and I would tell her that things are going well.

Q: That's very good. Do you remember if your school ever organized any activities? Was there anything that you found fun?

LJ: There were some activities, I don't remember clearly. We did go out for some activities like the Olympics.

Q: You went to Special Olympics?

LJ: I went to Special Olympics and something else which I forget.

Q: So you are not sure now, right? I heard from your mom that you participated in an artistic performance.

LJ: Right, there was an artistic performance.

Q: You danced?

LJ: Yes, I danced and played piano.

Q: You played piano?

LJ: Yeah.

Q: Wow, that's awesome. What did you play? 
LJ: Just one song, the twinkle little star one.

Q: Twinkle Twinkle Little Star, right?

LJ: Yeah.

Q: That's amazing. Did the schoolteacher teach you that?

LJ: Yup.

Q: It's great that you can play piano. Do you remember any friends you used to hang out with at school?

LJ: There's only one close friend, G.

$\mathrm{Q}$ : I heard about $\mathrm{G}$ from your mom. Anyone else?

LJ: Another friend whose last name was Ji. Just the two of them.

Q: Are you still in touch with G?

LJ: I lost my cell phone and her contact.

Q: Did you hang out at school?

LJ: Yeah, and we went out together too, like shopping. But I lost all of the information with my phone, so I can't find her and she can't find me.

Q: That's too bad.

LJ: Yeah. I don't remember where she lives. She used to live close by, but I don't know whether she still lives there or has moved. I've moved.

Q: Your mom said that you would help teachers do things at school, do you still remember?

LJ: Yes, I do.

Q: What did you help the teachers with?

LJ: I helped them organize what they needed for class before class started. Whatever they needed, I would get it ready. And once class started, they would just tell me what I needed to lay out on the desk or hand out to the students.

Q: Your mom also said that you often helped other kids, right?

LJ: Right.

Q: What did you help them with?

LJ: If there was anything they didn't understand, I would help them, like doing something, or reading, or writing. I was pretty popular.

Q: You got along well with them?

LJ: I did.

Q: If they had problems they didn't know how to solve, you would teach them, right?

LJ: Yup.

Q: They would ask you if there were things they couldn't do, and you would teach them too?

LJ: Right.

Q: It's very nice of you to offer to help. You were academic student leader. Did you have any other titles?

LJ: Right, I helped them with academics.

Q: Okay. So let's talk about your working at Papa John's. How long have you been with Papa John's?

LJ: Three or 4 years.

Q: Three or 4 years. Which store did you start with? 
LJ: I started with M store.

Q: Did you have any troubles or difficulties there?

LJ: No, I never had any difficulties there. People there were very nice and not discriminative. For example, because I have that certificate, some people would look at me differently, but people at that store didn't as far as I could tell.

$\mathrm{Q}$ : When you worked at M store, was there any co-worker you liked to hang out with?

LJ: There was. She was a manager, Ms. Lin. Sometimes I would meet up with her on my way to work and walk with her on my way back home. She lived pretty close, on Jintang Road, so it's right on my way home. Sometimes she worked morning shift and I did too, so I would meet up with her on my way to work. I lost my phone and her number, but I have her contact on WeChat. Since that store was shut down, I hadn't contacted her for a long time. And I am busy working at W store, so I don't really have much time to look her up. We have been in touch again recently and go out for dinner or shopping occasionally. Before that, we hadn't been in touch for a long time.

Q: So you got in touch with her again?

LJ: Yeah, because she is a nice person.

Q: That's good. You must be a nice person, too, otherwise she wouldn't get along with you so well, right?

LJ: Yeah.

Q: What do you do most of the time at Papa John's?

LJ: I work mostly in the kitchen, like kneading and tossing dough and adding ingredients. If someone takes a break, like at the appetizer counter, I will step in.

Q: You make appetizers too?

LJ: Yeah, I do. If someone takes a break from kneading and tossing dough, I will take over. When it's my turn to rest, they will knead and toss the dough.

Q: So everyone takes turns doing everything?

LJ: Yes, we rotate.

Q: You do everything and step in wherever someone is needed?

LJ: Right.

Q: What kind of appetizers do you make?

LJ: Salad, baked chicken wings. I also make noodles and rice. But if it gets busy, one person will be overwhelmed and will need another person to help, because however fast you work in the kitchen, they take orders faster in the dining area.

Q: I agree. So of all the things you can do, which one do you think you are best at?

LJ: I think kneading and tossing dough.

Q: I saw you doing that just now and you are really good at it. I wonder how you do it.

LJ: You press down on the edge of the dough before kneading and tossing it. The dough is ready made, as you can see. You just take it from the freezer and roll it in dry flour before kneading and tossing it to make it easier for you, then you spread the sauce and sprinkle the ingredients.

Q: I see. Do you also need to get the ingredients ready? 
LJ: Yes, I do. The ingredients always get used up. If you look at the counter there, I will need to refill, to chop, and to clean up, like what I just did. And the counter needs to be kept clean. Bottom line is that you should do everything you are supposed to do and shouldn't give anyone the chance to call you by name and say, "Come over here and get this done." If you see something that needs to be done, just do it, and when people see you like that, they will feel good, right? If they have to ask you to do something, even if you get it done, they won't feel good, right?

Q: Right. I saw how you worked and it was pretty smooth. You were wiping and cleaning, and it looked easy for you.

LJ: I am a neat person, you know. As soon as I see a slightly dirty cloth, I will wash it. As soon as I see some food dropped, I will dump it into the storage box, because I feel yucky if I see dirty stuff on the kitchen counters.

Q: Yeah, you are neat and organized. Your job actually looks tough. When you are not working, what do you do for fun?

LJ: I sleep. I stay up a bit late at night and sleep in in the morning. Then I go out shopping, or eat out, or catch a movie. I get tired after a day's work, and once I am home, I will do laundry and change into clean clothes. Clothes I wear at the store cannot be mixed with clothes I keep at home. I won't like it, because there's a greasy smell at the store. So when I go out, I wear clothes that don't smell. I wash my hair when I get home too. I can't sleep until I have washed everything clean. I don't want to go to bed with a greasy smell.

Q: You won't be able to fall asleep with that smell?

LJ: Right. I keep pants separate from other clothes, and work clothes separate from clothes I wear to go out.

Q: That's a very good habit. Do you travel?

LJ: I do. I traveled with my former co-workers. We went to Huang Mountain for the spa, for 5 days.

Q: Oh, Huang Mountain in Anhui. Do you remember where you went most recently? And how did you like it?

LJ: It was Huang Mountain, and I haven't been anywhere after that.

Q: How did you get to Huang Mountain? Did you make the travel plans yourself or did you make it as a group?

LJ: We made the plans together and booked tickets online together. I think I just filled out the ID and other information online. Then we went to the train station and scanned the barcode with our phones.

Q: It's awesome, that you can buy tickets online on your own. deal.

LJ: Right. The rest of the expenses, I just paid one place at a time. It was a package

Q: You were with a tour group?

LJ: Yes, and we paid separately for each place we visited. Like when we went to the spa, we just gave the entrance fee to the person collecting it. Different places charged different fees, you know.

Q: What about a hotel? Did you share a room with friends?

LJ: We shared.

Q: How many people went that time? 
LJ: Hmm, ten people.

Q: All females?

LJ: Right.

Q: Were you exhausted when you reached the top of Huang Mountain? It's a pretty high mountain.

LJ: I was really exhausted and the mountain is really high. The steps going up were pretty steep and I didn't know that I should have taken a walking stick. So I fell from time to time climbing the steep steps.

$\mathrm{Q}:$ You fell?

LJ: Yeah, and I scraped my knees. I couldn't see the step clearly before setting foot on it, so I missed and fell. Just scraped knees, no big deal. But the higher I climbed, the fresher the air felt, it was really nice. But it was freezing when I went.

Q: Yes, it's cold up on the mountains and you should have taken winter clothes.

LJ: I didn't expect it to be too cold, so I didn't take thick clothes. Once I was on the mountain, I felt so cold and my feet were all frozen. After we climbed the mountain, we went for the spa the next day. Since the spa was open even at night, we went there because we felt cold. It felt very comfortable soaking in the spa despite the cold.

Q: Did you watch the sunrise? Sunrise on Huang Mountain is beautiful.

LJ: I did, but didn't take many pictures.

Q: You can always go another time.

LJ: Right.

Q: You got transferred to W store only a short while ago. How are you adapting?

LJ: I have adapted well.

Q: Today I saw that your work is pretty tough. I also saw that you get along very well with co-workers who are older and you even joked with them sometimes. I remember one older co-worker saying that you really like to joke with her.

LJ: Right, that co-worker, because we get along well.

$\mathrm{Q}$ : Do you have other friends besides your co-workers?

LJ: No.

Q: So basically you just hang out with co-workers?

LJ: Right, mostly with them. I had some friends but we are hardly ever in touch now, so I don't know what's going on with them.

Q: You don't quite keep in touch so you drift apart. Your boyfriend ordered you takeout for lunch?

LJ: Yes, he ordered the takeout for me. He was checking what to get last night, and once I made up my mind, he ordered for me.

Q: That's very sweet of him. How long have you known each other?

LJ: More than 6 months.

Q: Does your mom know him?

LJ: She does.

Q: Your mom knows him?

LJ: Right. He has been to my house.

$\mathrm{Q}$ : Oh, he has been to your house?

LJ: Yeah. 
Q: That's great. Last time I went to your house for an interview, your mom hadn't mentioned it.

LJ: It was around Chinese New Year...

$\mathrm{Q}$ : That the relationship got serious?

LJ: Right, then I went to his house too.

Q: What do you think of him?

$\mathrm{LJ}$ : He is a decent guy.

Q: He takes good care of you, right?

LJ: Yeah.

Q: That's great. I am very happy to see you so happy. Okay, I think we are done here. Thank you very much.

LJ: You are welcome.

\section{Observation of $\mathbf{L J}$ at Work}

Observation date: 11:30-20:30, March 18, 2017

Observation place: Restaurant where LJ works

Observer and writer: Zhen Wei

Note: Some of LJ's co-workers were included in the observation. They were Mr. $\mathrm{S}$ (who is an employee being cared for), Ms. Li, and Mr. Jiang.

\begin{tabular}{|c|c|c|}
\hline Time & What LJ did & Remarks \\
\hline 11:20 & $\begin{array}{l}\text { Changed into work clothes, put on } \\
\text { apron, washed hands, and got ready } \\
\text { for work }\end{array}$ & $\begin{array}{l}\text { Talked and laughed with co-workers. } \\
\text { Looked relaxed and happy }\end{array}$ \\
\hline $11: 25$ & $\begin{array}{l}\text { Put a big bag of potato wedges in the } \\
\text { fridge }\end{array}$ & \\
\hline $11: 30$ & $\begin{array}{l}\text { S was next to her and making } \\
\text { appetizers. LJ got the tuna spaghetti } \\
\text { for him, put it in a container and } \\
\text { warmed it up in the microwave }\end{array}$ & $\begin{array}{l}\text { Told S, "The spaghetti needs to be } \\
\text { warmed up a little in the microwave." }\end{array}$ \\
\hline
\end{tabular}


(continued)

\begin{tabular}{|c|c|c|}
\hline Time & What LJ did & Remarks \\
\hline $11: 35-11: 50$ & $\begin{array}{l}\text { Took two big bags of stringed squid } \\
\text { from the fridge. Put on disposable } \\
\text { gloves before grabbing a fistful of the } \\
\text { squid from the bag and putting it in a } \\
\text { Ziplock bag to be weighed on an } \\
\text { electronic scale. Checked the weight. } \\
\text { If it weighed more than } 120 \mathrm{~g} \text {, } \\
\text { transferred some from the Ziplock bag } \\
\text { back to the big bag. And added more } \\
\text { if it weighed less than } 120 \mathrm{~g} \text {. Made } \\
\text { sure that every Ziplock bag weighed } \\
\text { around } 120 \mathrm{~g} \text { (or } 118 \mathrm{~g} \text { or } 122 \mathrm{~g} \text { ). } \\
\text { Sealed the Ziplock bags. Wiped the } \\
\text { work counter once in the middle of } \\
\text { weighing the squid }\end{array}$ & $\begin{array}{l}\text { She was good at what she did and told } \\
\text { the observer that she was doing this } \\
\text { for the sake of convenience, because } \\
\text { once the customer placed the order, } \\
\text { she could just take a small bag to bake }\end{array}$ \\
\hline $11: 52$ & $\begin{array}{l}\text { Prepared a } 200 \text {-g baked rice with } \\
\text { chicken. Put cooked rice in the box } \\
\text { and added eight pieces of chicken and } \\
\text { shredded cheese. Spread the } \\
\text { ingredients evenly before putting the } \\
\text { box in the oven }\end{array}$ & \\
\hline 11:54 & $\begin{array}{l}\text { S was still next to her and making a } \\
\text { chef's sampler plate. LJ took the plate } \\
\text { from him and flipped the chicken } \\
\text { wings over before putting the plate in } \\
\text { the oven }\end{array}$ & $\begin{array}{l}\text { Told S, "Can you flip the chicken } \\
\text { wings over?" }\end{array}$ \\
\hline $11: 55$ & $\begin{array}{l}\text { Put the small bags of stringed squid } \\
\text { that she had just weighed into a big } \\
\text { bag before putting the big bag in the } \\
\text { fridge }\end{array}$ & \\
\hline $11: 58-12: 15$ & $\begin{array}{l}\text { Weighed potato wedges. Took a big } \\
\text { bag of potato wedges from the fridge. } \\
\text { Put on disposable gloves before } \\
\text { grabbing a fistful of the potato wedges } \\
\text { from the bag and putting it in a } \\
\text { Ziplock bag to be weighed. If it } \\
\text { weighed more than } 100 \mathrm{~g} \text {, transferred } \\
\text { some from the Ziplock bag back to the } \\
\text { big bag. And added more if it weighed } \\
\text { less than } 100 \text { g. Made sure that every } \\
\text { Ziplock bag weighed around } 100 \mathrm{~g} \\
\text { (98-102 g). Sealed the Ziplock bags } \\
\text { Asked S to hand her Ziplock bags } \\
\text { while weighing the potato wedges }\end{array}$ & $\begin{array}{l}\text { Chatted with S. S said to LJ, "It was } \\
\text { so busy yesterday. No one helped me } \\
\text { but I was able to handle everything on } \\
\text { my own." } \\
\text { LJ told observer, "We help each other. } \\
\text { I was worried that S would be } \\
\text { overwhelmed." } \\
\text { S told the observer, "It's easier when } \\
\text { LJ is here. We can help each other." }\end{array}$ \\
\hline 12:06 & $\begin{array}{l}\text { A co-worker making pizza asked to } \\
\text { borrow LJ's scissors and LJ handed } \\
\text { them to her }\end{array}$ & \\
\hline
\end{tabular}


(continued)

\begin{tabular}{|c|c|c|}
\hline Time & What LJ did & Remarks \\
\hline $\begin{array}{l}12: 12 \\
12: 18\end{array}$ & $\begin{array}{l}\text { Stopped the weighing job and } \\
\text { prepared Italian-style baked rice with } \\
\text { beef. S put the rice in and LJ added } \\
\text { chicken, walnut and cheese before } \\
\text { putting everything in the oven } \\
\text { Put the small bags of potato wedges } \\
\text { she had finished weighing into a big } \\
\text { bag and put the big bag into the fridge. } \\
\text { Cleaned up the work counter, moved } \\
\text { the electronic scale aside, and mopped } \\
\text { the counter }\end{array}$ & $\begin{array}{l}\text { Told S to go to the service counter to } \\
\text { make sure there was enough beef stew } \\
\text { and reminded him to put beef sauce in } \\
\text { the thermo box to keep it from drying } \\
\text { up, otherwise the customers might } \\
\text { complain }\end{array}$ \\
\hline $12: 21$ & $\begin{array}{l}\text { Made pizza. Li kneaded and tossed } \\
\text { the dough and placed it on the counter. } \\
\text { LJ spread ketchup on it and added and } \\
\text { spread multiple ingredients evenly } \\
\text { before putting the pizza in the oven }\end{array}$ & $\begin{array}{l}\text { She was smooth at what she did and } \\
\text { knew the right amount of ingredients } \\
\text { to add. She told the observer that } \\
\text { cheese was used in different amounts, } \\
\text { such as a full cup, half a cup, or two } \\
\text { thirds of a cup }\end{array}$ \\
\hline $12: 23$ & $\begin{array}{l}\text { Took over a pizza with ingredients } \\
\text { already added, spread cheese on top } \\
\text { and put the pizza in the oven }\end{array}$ & \\
\hline $12: 24$ & $\begin{array}{l}\text { Took over the spaghetti that S had } \\
\text { made, added cheese and decoration } \\
\text { (Dutch celery), and delivered it to the } \\
\text { service counter }\end{array}$ & \\
\hline $12: 26$ & $\begin{array}{l}\text { Washed the cloth and put the clean } \\
\text { mop on the work counter for making } \\
\text { pizza }\end{array}$ & $\begin{array}{l}\text { Chatted with an older co-worker while } \\
\text { washing the cloth. Looked relaxed and } \\
\text { happy }\end{array}$ \\
\hline $12: 28$ & $\begin{array}{l}\text { Made three cheese sausages, laid them } \\
\text { out on the baking pan and put the pan } \\
\text { in the oven }\end{array}$ & \\
\hline $12: 29$ & $\begin{array}{l}\text { Made a 6-inch pizza. Spread sauce on } \\
\text { the dough that had been kneaded and } \\
\text { tossed, added ingredients and put } \\
\text { everything in the oven }\end{array}$ & $\begin{array}{l}\text { Wrote "big" and "make smaller" to } \\
\text { tell the co-worker kneading and } \\
\text { tossing the dough (who is deaf and } \\
\text { mute) that the dough he had just made } \\
\text { was too big and should be smaller }\end{array}$ \\
\hline $12: 31$ & Made a 9-inch pizza & $\begin{array}{l}\text { Told the observer the name of each } \\
\text { ingredient }\end{array}$ \\
\hline $12: 33$ & Made a 12-inch pizza & $\begin{array}{l}\text { Told the observer that the cheese cup } \\
\text { had two different measurements. One } \\
\text { side measured a full cup and the other } \\
\text { side measured half a cup }\end{array}$ \\
\hline $12: 35$ & Made a 9-inch pizza & $\begin{array}{l}\text { Told the observer that this pizza was } \\
\text { thin-crust }\end{array}$ \\
\hline $12: 37$ & Made a 9-inch pizza & \\
\hline $12: 39$ & Made a 9-inch pizza & $\begin{array}{l}\text { Asked a co-worker to get her some } \\
\text { sliced ham }\end{array}$ \\
\hline
\end{tabular}


(continued)

\begin{tabular}{|c|c|c|}
\hline Time & What LJ did & Remarks \\
\hline 12:41 & Made a 9-inch pizza & $\begin{array}{l}\text { Manager Li asked LJ, "Is that how } \\
\text { you spread the pepperoni?" } \\
\text { LJ reorganized the pepperoni }\end{array}$ \\
\hline $12: 43$ & $\begin{array}{l}\text { Washed hands and wiped the work } \\
\text { counter }\end{array}$ & \\
\hline 12:45 & Made a 9-inch pizza & \\
\hline $12: 47$ & Made a 9-inch pizza & \\
\hline $12: 50-12: 55$ & Made a 12-inch pizza & $\begin{array}{l}\text { Told the observer that she was making } \\
\text { combo pizza which was more } \\
\text { complicated than making other kinds } \\
\text { of pizza }\end{array}$ \\
\hline $12: 56$ & Made a 9-inch half-half pizza & \\
\hline $12: 58$ & $\begin{array}{l}\text { Prepared ham. Took a big bag of } \\
\text { sliced ham from the fridge, cut the bag } \\
\text { open and emptied the ham into a } \\
\text { storage box to be used later }\end{array}$ & \\
\hline $12: 59$ & Made pizza & $\begin{array}{l}\text { Li gave the dough she had just } \\
\text { kneaded and tossed to LJ and said, } \\
\text { "Here you go, girl." }\end{array}$ \\
\hline 13:01 & $\begin{array}{l}\text { Cleaned up the work counter. Dumped } \\
\text { the cheese that had fallen onto the } \\
\text { plate when she was spreading } \\
\text { ingredients into the cheese storage box }\end{array}$ & \\
\hline 13:03 & $\begin{array}{l}\text { Took the pizza dough from LJ to } \\
\text { spread the durian sauce. Saw that the } \\
\text { storage box was misplaced and asked } \\
\text { Li to come over and put it in the right } \\
\text { place }\end{array}$ & $\begin{array}{l}\text { LJ pointed at the storage box and said, } \\
\text { "Ms. Li, can you please come and put } \\
\text { this back?" }\end{array}$ \\
\hline 13:05 & $\begin{array}{l}\text { While wiping the work counter, swept } \\
\text { cheese that had been dropped on the } \\
\text { counter into a pile and dumped it into } \\
\text { the trash can next to the counter }\end{array}$ & \\
\hline 13:07 & $\begin{array}{l}\text { Took the cheese and emptied it into } \\
\text { the storage box }\end{array}$ & \\
\hline 13:10 & $\begin{array}{l}\text { Organized pizza nets, stacked them } \\
\text { according to size and placed them on } \\
\text { the shelf }\end{array}$ & \\
\hline 13:12 & Made pizza & $\begin{array}{l}\text { Chatted with Li. Li said it was hot, so } \\
\text { LJ asked Li to go drink water } \\
\text { Talked with a new co-worker about } \\
\text { the dough he kneaded and tossed }\end{array}$ \\
\hline
\end{tabular}


(continued)

\begin{tabular}{|c|c|c|}
\hline Time & What LJ did & Remarks \\
\hline 13:15 & Made pizza & $\begin{array}{l}\text { Continued to talk about the dough } \\
\text { kneaded and tossed by the new } \\
\text { co-worker. The new co-worker said, } \\
\text { "LJ is so good at kneading and tossing } \\
\text { dough. We should learn from her. She } \\
\text { knows everything." }\end{array}$ \\
\hline 13:18 & $\begin{array}{l}\text { Cleaned up the work counter and } \\
\text { wiped the plates }\end{array}$ & \\
\hline $13: 23$ & $\begin{array}{l}\text { Took appetizers out of the oven and } \\
\text { delivered them to the service counter }\end{array}$ & \\
\hline 13:26 & Made pizza & \\
\hline 13:27 & Washed a storage box & \\
\hline 13:29 & $\begin{array}{l}\text { Took precut tomatoes from the cabinet } \\
\text { and put them in the storage box. } \\
\text { Washed a storage box }\end{array}$ & \\
\hline $13: 31$ & Made pizza & $\begin{array}{l}\text { Asked } \mathrm{Li} \text {, "Is there red pepper in this } \\
\text { pizza?" Li said "No." LJ then } \\
\text { remembered that this was a veggie } \\
\text { pizza that should not have red pepper, } \\
\text { so she took off the red pepper she had } \\
\text { put on }\end{array}$ \\
\hline $13: 38$ & Made pizza with curled crust & $\begin{array}{l}\text { Talked with Li about a handsome guy } \\
\text { who had started working in the dining } \\
\text { area. LJ told the observer that the guy } \\
\text { was Manager Sun's son. Looked } \\
\text { relaxed and happy }\end{array}$ \\
\hline $13: 42$ & Made sampler plate & \\
\hline 13:44 & Made pizza & $\begin{array}{l}\text { LJ asked another older co-worker to } \\
\text { get her a bag of sliced mushrooms }\end{array}$ \\
\hline 13:46 & $\begin{array}{l}\text { Put the bagged, sliced mushrooms } \\
\text { into the storage box }\end{array}$ & \\
\hline $13: 47-13: 53$ & $\begin{array}{l}\text { Made pizza (Made four without } \\
\text { stopping.) }\end{array}$ & $\begin{array}{l}\text { Li reminded her, "Double-check the } \\
\text { ordering machine, girl." }\end{array}$ \\
\hline 13:55 & $\begin{array}{l}\text { Fixed the dough. The new co-worker } \\
\text { made a hole in the dough when he } \\
\text { tossed it. LJ was responsible for fixing } \\
\text { it by tossing and squeezing the dough }\end{array}$ & $\begin{array}{l}\text { Told the new co-worker, "Have you } \\
\text { ever played with Play-Doh? This is } \\
\text { like playing with Play-Doh." }\end{array}$ \\
\hline 13:57 & Made pizza & \\
\hline 13:59 & Kneaded and tossed dough & \\
\hline 14:01 & $\begin{array}{l}\text { Took dough from the freezer and put it } \\
\text { on the work counter. Stacked the } \\
\text { storage box with dough inside } \\
\text { underneath the storage box without } \\
\text { dough inside }\end{array}$ & $\begin{array}{l}\text { Asked a co-worker to let her pass, } \\
\text { saying, "Let me squeeze by you." }\end{array}$ \\
\hline
\end{tabular}


(continued)

\begin{tabular}{|c|c|c|}
\hline Time & What LJ did & Remarks \\
\hline 14:03-14:08 & Kneaded and tossed dough & $\begin{array}{l}\text { LJ was responsible for kneading and } \\
\text { tossing dough while two older } \\
\text { co-workers added ingredients. They } \\
\text { worked together on making pizzas } \\
\text { Reminded one of the co-workers to } \\
\text { spread ketchup }\end{array}$ \\
\hline 14:09 & $\begin{array}{l}\text { Cleaned up the counter she had just } \\
\text { worked at. Washed hands }\end{array}$ & $\begin{array}{l}\text { Chatted with } \mathrm{Li} \text {, who was having } \\
\text { lunch, about the TV show Three } \\
\text { Lifetimes among Plum Flowers }\end{array}$ \\
\hline 14:12 & $\begin{array}{l}\text { Returned to the work counter and } \\
\text { together with an older co-worker, } \\
\text { emptied sliced mushrooms and cheese } \\
\text { sticks into the storage boxes }\end{array}$ & $\begin{array}{l}\text { Chatted with the co-worker and } \\
\text { looked relaxed and happy. Put her } \\
\text { hand on the co-worker's shoulder. The } \\
\text { co-worker gently slapped her hand } \\
\text { and joked, "As if I am not already } \\
\text { exhausted." LJ smiled and took her } \\
\text { hand down }\end{array}$ \\
\hline $14: 16-14: 20$ & $\begin{array}{l}\text { Washed dishes and the cloth, wiped } \\
\text { the work counter, and put trash in the } \\
\text { trash can }\end{array}$ & \\
\hline $14: 21$ & $\begin{array}{l}\text { Kneaded and tossed dough. Made } \\
\text { pizza }\end{array}$ & $\begin{array}{l}\text { Made a 9-inch pizza with curled crust } \\
\text { all on her own }\end{array}$ \\
\hline $14: 24$ & $\begin{array}{l}\text { Taught a new co-worker how to knead } \\
\text { and toss dough and helped spread the } \\
\text { dough wider }\end{array}$ & $\begin{array}{l}\text { The manager asked the new co-worker } \\
\text { to practice more, and LJ took it upon } \\
\text { herself to teach him }\end{array}$ \\
\hline $14: 26$ & $\begin{array}{l}\text { Used tools to take a baked pizza from } \\
\text { the oven, sliced it in four and } \\
\text { delivered it to the service counter }\end{array}$ & \\
\hline $14: 30-14: 38$ & Kneaded and tossed dough & $\begin{array}{l}\text { Also made a sauerkraut and pork } \\
\text { pizza. While spreading the sauce, } \\
\text { asked an older co-worker next to her } \\
\text { whether there was any sauerkraut left }\end{array}$ \\
\hline $14: 40$ & Went to the freezer to get dough & \\
\hline $14: 41$ & Made pizza & \\
\hline $14: 43$ & $\begin{array}{l}\text { Went to the freezer to get sliced } \\
\text { sausages }\end{array}$ & \\
\hline $14: 48$ & $\begin{array}{l}\text { Emptied onion and green pepper into } \\
\text { the storage boxes }\end{array}$ & \\
\hline $14: 50-14: 58$ & $\begin{array}{l}\text { Cut meat slices. Stacked two slices } \\
\text { together before cutting them in half }\end{array}$ & \\
\hline $15: 00-15: 03$ & Made pizza & $\begin{array}{l}\text { LJ got cheese sticks for an older } \\
\text { co-worker and then asked her to grab } \\
\text { some diced pork for her }\end{array}$ \\
\hline
\end{tabular}


(continued)

\begin{tabular}{|c|c|c|}
\hline Time & What LJ did & Remarks \\
\hline $15: 00-16: 00$ & Break. Lunch & $\begin{array}{l}\text { LJ had takeout for lunch, which was } \\
\text { followed by our interview. Then she } \\
\text { played a little on her cell phone before } \\
\text { resting with her elbows on the table }\end{array}$ \\
\hline 16:00 & $\begin{array}{l}\text { Put on apron, washed hands, and put } \\
\text { on disposable gloves }\end{array}$ & Got ready for work \\
\hline $16: 10$ & $\begin{array}{l}\text { Put onion rings and star-shaped } \\
\text { potatoes on the baking pan and put the } \\
\text { pan in the oven }\end{array}$ & \\
\hline $16: 15$ & $\begin{array}{l}\text { Made appetizers including sampler } \\
\text { plate }\end{array}$ & \\
\hline $16: 17$ & $\begin{array}{l}\text { Worked with Li on making a combo } \\
\text { pizza. Was responsible for rolling } \\
\text { meat slices and squeezing garlic sauce }\end{array}$ & \\
\hline $16: 25-16: 55$ & $\begin{array}{l}\text { Was responsible for taking baked } \\
\text { pizzas or appetizers from the pans, } \\
\text { slicing the pizzas, arranging the plates, } \\
\text { and boxing to-go pizzas and appetizers }\end{array}$ & $\begin{array}{l}\text { She boxed to-go orders and made time } \\
\text { to go to the ordering machine to print } \\
\text { orders. During afternoon peak hour, } \\
\text { she had to box one to-go order almost } \\
\text { every } 2 \text { min }\end{array}$ \\
\hline $17: 00-17: 05$ & Made pizzas & Made a total of three pizzas \\
\hline 17:06 & $\begin{array}{l}\text { Boxed a to-go pizza and delivered it to } \\
\text { the service counter }\end{array}$ & \\
\hline 17:08 & Emptied chicken into the storage box & \\
\hline 17:09 & $\begin{array}{l}\text { Cooked rice: Put rice in the inner pan } \\
\text { of the rice cooker, rinsed the rice, } \\
\text { added sauces, stirred it evenly before } \\
\text { adding water, put the pan back in the } \\
\text { rice cooker and turned on the rice } \\
\text { cooker }\end{array}$ & $\begin{array}{l}\text { Manager } \mathrm{Li} \text { came over and checked on } \\
\text { what } \mathrm{LJ} \text { was doing }\end{array}$ \\
\hline $17: 12-17: 20$ & Made pizzas & Made a total of four pizzas \\
\hline $17: 22$ & $\begin{array}{l}\text { Prepared cheese powder and diced } \\
\text { pork and emptied them into the } \\
\text { storage boxes }\end{array}$ & \\
\hline $17: 24-17: 28$ & Made pizzas & \\
\hline $17: 30$ & Bagged cherry tomatoes & \\
\hline $17: 32-17: 55$ & Made pizzas & $\begin{array}{l}\text { Made one pizza every } 2 \text { min on } \\
\text { average }\end{array}$ \\
\hline 17:56-18:06 & Rolled bacon & \\
\hline 18:08-18:35 & Made pizzas & \\
\hline $18: 37$ & Prepared cheese sticks & \\
\hline $18: 40$ & Used microwave to heat ingredients & \\
\hline
\end{tabular}


(continued)

\begin{tabular}{|c|c|c|}
\hline Time & What LJ did & Remarks \\
\hline 18:42-19:20 & Made pizzas & $\begin{array}{l}\text { Jiang was responsible for kneading } \\
\text { and tossing dough and LJ was } \\
\text { responsible for the rest of the work. } \\
\text { Made one pizza every } 2 \text { min on } \\
\text { average }\end{array}$ \\
\hline 19:25-19:38 & Organized disposable cups & \\
\hline 19:50 & $\begin{array}{l}\text { Kneaded and tossed dough. Made } \\
\text { pizzas }\end{array}$ & \\
\hline 20:00 & $\begin{array}{l}\text { Used cloth to clean up the work } \\
\text { counter }\end{array}$ & \\
\hline $20: 10$ & $\begin{array}{l}\text { Kneaded and tossed dough. Made } \\
\text { pizzas }\end{array}$ & \\
\hline 20:15-20:20 & Made pizzas & $\begin{array}{l}\text { Jiang was responsible for kneading } \\
\text { and tossing dough and } \mathrm{LJ} \text { was } \\
\text { responsible for the rest of the work }\end{array}$ \\
\hline $20: 25$ & $\begin{array}{l}\text { Delivered a sliced pizza to the service } \\
\text { counter }\end{array}$ & \\
\hline $20: 30$ & $\begin{array}{l}\text { Punched card, washed hands, took off } \\
\text { work clothes, and got ready to go } \\
\text { home }\end{array}$ & $\begin{array}{l}\text { Chatted with co-workers. Said "bye" } \\
\text { to the observer }\end{array}$ \\
\hline
\end{tabular}

Translated by Cissy Zhao Edited by Andy Boreham and Zijian Chen

Open Access This chapter is licensed under the terms of the Creative Commons Attribution 4.0 International License (http://creativecommons.org/licenses/by/4.0/), which permits use, sharing, adaptation, distribution and reproduction in any medium or format, as long as you give appropriate credit to the original author(s) and the source, provide a link to the Creative Commons license and indicate if changes were made.

The images or other third party material in this chapter are included in the chapter's Creative Commons license, unless indicated otherwise in a credit line to the material. If material is not included in the chapter's Creative Commons license and your intended use is not permitted by statutory regulation or exceeds the permitted use, you will need to obtain permission directly from the copyright holder.

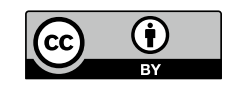

